\title{
Activators and Inhibitors of Protein Kinase C (PKC): Their Applications in Clinical Trials
}

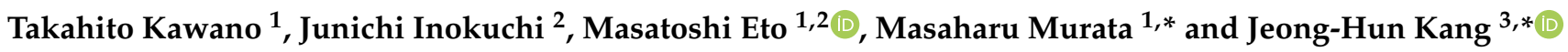 \\ 1 Center for Advanced Medical Innovation, Kyushu University, 3-1-1 Maidashi, Higashi-ku, Fukuoka 812-8582, Japan; \\ t-kawano@dem.med.kyushu-u.ac.jp (T.K.); etom@uro.med.kyushu-u.ac.jp (M.E.) \\ 2 Department of Urology, Graduate School of Medical Sciences, Kyushu University, 3-1-1 Maidashi, \\ Higashi-ku, Fukuoka 812-8582, Japan; junichi@uro.med.kyushu-u.ac.jp \\ 3 Division of Biopharmaceutics and Pharmacokinetics, National Cerebral and Cardiovascular Center Research \\ Institute, 6-1 Shinmachi, Kishibe, Suita 564-8565, Japan \\ * Correspondence: m-murata@dem.med.kyushu-u.ac.jp (M.M.); jrjhkang@ncvc.go.jp (J.-H.K.)
}

check for updates

Citation: Kawano, T.; Inokuchi, J.; Eto, M.; Murata, M.; Kang, J.-H. Activators and Inhibitors of Protein Kinase C (PKC): Their Applications in Clinical Trials. Pharmaceutics 2021, 13, 1748. https://doi.org/10.3390/ pharmaceutics 13111748

Academic Editor: Katarzyna Malarz

Received: 8 September 2021

Accepted: 19 October 2021

Published: 20 October 2021

Publisher's Note: MDPI stays neutral with regard to jurisdictional claims in published maps and institutional affiliations.

Copyright: (c) 2021 by the authors. Licensee MDPI, Basel, Switzerland. This article is an open access article distributed under the terms and conditions of the Creative Commons Attribution (CC BY) license (https:// creativecommons.org/licenses/by/ $4.0 /)$.
Abstract: Protein kinase C (PKC), a family of phospholipid-dependent serine/threonine kinase, is classed into three subfamilies based on their structural and activation characteristics: conventional or classic PKC isozymes (cPKCs; $\alpha, \beta I, \beta I I$, and $\gamma$ ), novel or non-classic PKC isozymes (nPKCs; $\delta, \varepsilon, \eta$, and $\theta$ ), and atypical PKC isozymes (aPKCs; $\zeta$, $\iota$, and $\lambda$ ). PKC inhibitors and activators are used to understand PKC-mediated intracellular signaling pathways and for the diagnosis and treatment of various PKC-associated diseases, such as cancers, neurological diseases, cardiovascular diseases, and infections. Many clinical trials of PKC inhibitors in cancers showed no significant clinical benefits, meaning that there is a limitation to design a cancer therapeutic strategy targeting PKC alone. This review will focus on the activators and inhibitors of PKC and their applications in clinical trials.

Keywords: protein kinase C; cancer; inhibitor; activator; signaling pathway; clinical trial

\section{Introduction}

Protein kinase C (PKC) is a family of phospholipid-dependent serine/threonine kinases and is classified into three subfamilies based on their structural and activation characteristics: conventional or classic PKC isozymes (cPKCs; $\alpha, \beta \mathrm{I}, \beta \mathrm{II}$, and $\gamma$ ), novel or non-classic PKC isozymes (nPKCs; $\delta, \varepsilon, \eta$, and $\theta$ ), and atypical PKC isozymes (aPKCs; $\zeta, \iota$, and $\lambda$ ) (Figure 1) [1-3]. Consensus phosphorylation site motifs for PKCs are $(R / K) X(S / T)$, $(\mathrm{R} / \mathrm{K})(\mathrm{R} / \mathrm{K}) \mathrm{X}(\mathrm{S} / \mathrm{T}),(\mathrm{R} / \mathrm{K}) \mathrm{XX}(\mathrm{S} / \mathrm{T}),(\mathrm{R} / \mathrm{K}) \mathrm{X}(\mathrm{S} / \mathrm{T}) \mathrm{XR} / \mathrm{K}$, and $(\mathrm{R} / \mathrm{K}) \mathrm{XX}(\mathrm{S} / \mathrm{T}) \mathrm{XR} / \mathrm{K}$, meaning that their substrates are typically rich in basic amino acids (arginine $(R)$ and/or lysine (K)) [4].

PKCs are involved in multiple signal transduction systems that control cell proliferation, differentiation, survival, invasion, migration, and apoptosis. For these reasons, PKCs are regarded as important targets for the treatment of various diseases, such as cancers, neurological diseases (e.g., Alzheimer's disease (AD)), cardiovascular diseases (e.g., heart failure), and infections (e.g., acquired immunodeficiency syndrome) (for review see [2,5-7]). PKC inhibitors and activators can be used for the treatment of various PKC-associated diseases. In this review, we will focus on the activators and inhibitors of PKC and their applications in clinical trials. 


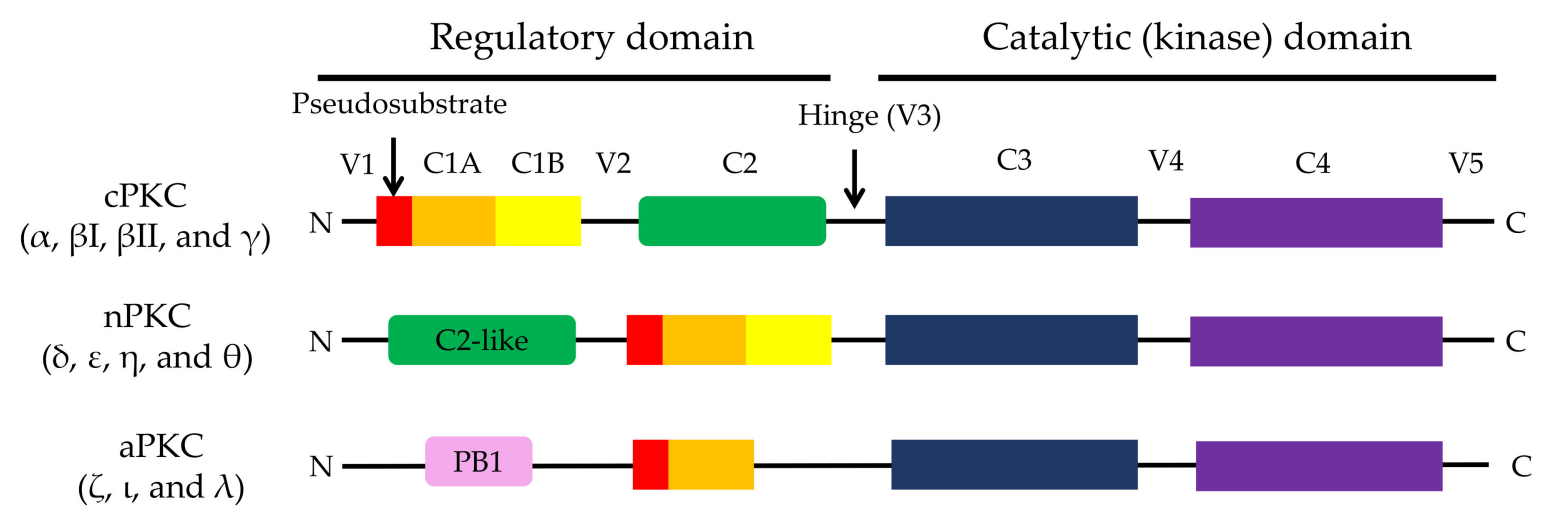

Figure 1. Structure of PKC isozymes. All PKCs consist of a regulatory domain, a catalytic (kinase) domain, and variable regions (V1-V5). The regulatory domain of all PKCs includes a C1 domain with a pseudosubstrate motif. Additionally, cPKCs, nPKC, and aPKCs have a C2 domain that binds to $\mathrm{Ca}^{2+}$, a C2-like domain that cannot bind to $\mathrm{Ca}^{2+}$, and a PB1 domain in the regulatory region, respectively. The $\mathrm{C} 3$ and the $\mathrm{C} 4$ domain of all PKCs bind to ATP and substrate, respectively. Reproduced with permission from Kang, J.H. et al., Biotechnol. Adv.; published by Elsevier, 2012.

\section{Structure of PKC Isozymes}

Several important review articles have already been reported regarding the structure of PKC isozymes [1-3]. All PKC isozymes consist of a regulatory domain containing the $\mathrm{C} 1$ and C2 domains, a catalytic (kinase) domain containing C3 (N-terminal lobe (N-lobe) domain) and C4 domain (C-terminal lobe (C-lobe) domain), and variable regions (V1-V5) (Figure 1). While the $\mathrm{C} 1$ domain of cPKCs and nPKCs interacts with diacylglycerol (DAG), the single $\mathrm{C} 1$ domain of aPKCs cannot bind to DAG. The C2 domain of CPKCs binds to $\mathrm{Ca}^{2+}$, but not the C2-like domain of nPKCs. The C3 domain contains an ATP-binding site, and the $\mathrm{C} 4$ domain has a substrate-binding site. Although all PKC isozymes do not contain the phosphatidylserine (PS)-binding domain, PS, either alone or with DAG and $\mathrm{Ca}^{2+}$, is essential for PKC activation [1-3].

The regulatory region of all PKC isozymes contains an autoinhibitory pseudosubstrate domain that inhibits kinase activity by interacting with the substrate binding site within the catalytic region. The catalytic domain contains three phosphorylation motifs: an activation loop, a turn motif, and a hydrophobic motif [1-3]. Moreover, aPKCs have a protein-protein-interacting region known as Phox and Bem 1 (PB1) at the N-terminus of the regulatory domain. The PB1 domain binds with partitioning-defective protein 6 (Par6), p62 (also known as sequestosome 1, SQSTM1), or mitogen-activated protein kinase kinase 5 (MEK5) [8,9].

\section{PKC Inhibitors}

Most of PKC inhibitors are C3 domain-binding inhibitors (ATP competitive PKC inhibitors), but $\mathrm{C} 1$ domain- (DAG competitive PKC inhibitors) and C4 domain-binding PKC inhibitors (substrate competitive PKC inhibitors) have also been reported. Among the C1-domain binding agents, bryostatin-1 acts as both an activator and inhibitor of PKC.

\subsection{C1 Domain-Binding PKC Inhibitors (DAG Competitive PKC Inhibitors)}

Several C1 domain-binding PKC inhibitors have been reported, such as calphostin C (UCN-1028C), a compound isolated from a dark pigmented mold, Cladosporium cladosporioides (half-maximum inhibitory concentration $\left(\mathrm{IC}_{50}\right)=0.05 \mu \mathrm{M}$ for rat brain PKC) [10,11], 2,6-diamino-N-([1-oxotridecyl)-2-piperidinyl] methyl) hexanamide (NPC 15437), a synthetically derived compound ( $\mathrm{IC}_{50}=22 \mu \mathrm{M}$ for PKC $\alpha$ [12] and $19 \mu \mathrm{M}$ for rat brain PKC [13]), $\mathrm{N}$-benzyladriamycin-14-valerate $\left(\mathrm{AD} 198 ; \mathrm{IC}_{50}=9 \mu \mathrm{M}\right.$ for the binding of phorbol 12, 13dibutyrate (PDBu) to rat brain $\mathrm{PKC}$ ), a lipophilic anthracycline [14], and resveratrol, a polyphenolic phytoaxelin present in dietary sources $\left(\mathrm{IC}_{50}=2 \mu \mathrm{M}\right.$ for PKC $\alpha$ ) [15] (Figure 2). There are no reports regarding the use of these inhibitors in clinical trials. 


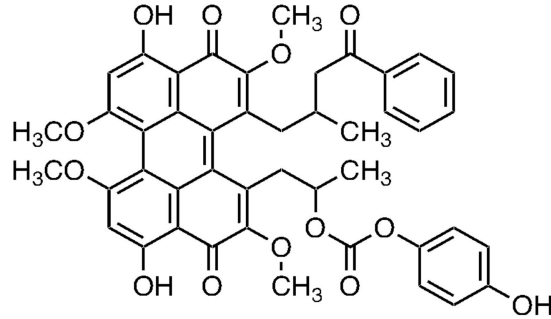

Calphostin C (UCN-1028C)

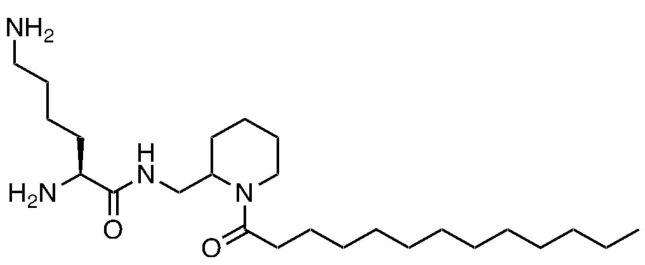

2,6-diamino- $N-([1-o x o t r i d e c y l)-2-$ piperidinyl]methyl)hexanamide

(NPC 15437)

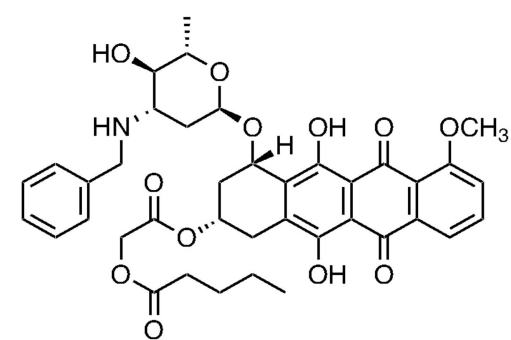

$N$-benzyladriamycin-14-valerate<smiles>CCCCCCCCCCCCCCC(O)C(N)CO</smiles>

Safingol

Figure 2. Chemical structure of $\mathrm{C} 1$ domain-binding PKC inhibitors (DAG competitive PKC inhibitors).

On the other hand, safingol (L-threo-dihydrosphingosine), a lyso-sphingolipid PKC inhibitor, can also interact with the $\mathrm{C} 1$ domain and inhibit the enzymatic activity and $\left[{ }^{3} \mathrm{H}\right]$ PDBu binding of purified rat brain PKC with similar IC $_{50}$ values $(37.5$ and $31 \mu \mathrm{M}$, respectively) [16]. A pilot phase I study of safingol alone or in combination with doxorubicin in tumor-bearing animals suggested that safingol could be administered safely along with $45 \mathrm{mg} / \mathrm{m}^{2}$ of doxorubicin [17]. Furthermore, in a phase I clinical trial of safingol in combination with cisplatin in advanced solid tumors, the recommended phase II dose was safe (safingol $\left(840 \mathrm{mg} / \mathrm{m}^{2}\right)$ and cisplatin $\left.\left(60 \mathrm{mg} / \mathrm{m}^{2}\right)\right)$ when administered every 3 weeks. However, in this phase I trial, safingol was used as an inhibitor of sphingosine kinase 1, which produces sphingosine 1-phosphate, that is associated with cancer cell growth and proliferation, and not as a PKC inhibitor [18]. Currently, a phase I clinical trial of safingol plus all-trans- $\mathrm{N}$-(4-hydroxyphenyl) retinamide (fenretinide) is ongoing in patients with relapsed malignancies (NCT01553071).

\subsection{C2 Domain-Binding PKC Inhibitors ( $\mathrm{Ca}^{2+}$ Competitive PKC Inhibitors)}

cPKC isozymes contain a $\mathrm{C} 2$ domain that binds to $\mathrm{Ca}^{2+}$, and the nPKC isozymes have a C2-like domain that cannot bind to $\mathrm{Ca}^{2+}$ but binds to phosphotyrosines [19]. There are no reports regarding PKC inhibitors that can block the interaction with the $\mathrm{C} 2$ domain. However, PKC $\beta$ C2 region-derived peptides, such as C2-1 (KQKTKTIK), C2-2 (MDPNGLSDPYVKL), and C2-4 (SLNPEWNET), inhibit the binding of PKC $\beta$ C2 fragment to the receptor for activated C-kinase (RACK). These peptide inhibitions specifically block the translocation and function of $\mathrm{CPKC}$ isozymes containing the $\mathrm{C} 2$ domain, but not $\mathrm{nPKC}$ isozymes containing the C2-like domain $[20,21]$.

\subsection{C3 Domain (N-Lobe Domain)-Binding PKC Inhibitors (ATP Competitive PKC Inhibitors)}

Among PKC inhibitors, ATP competitive small molecule inhibitors have been broadly developed and applied in clinical trials. ATP competitive inhibitors interact with the ATPbinding pocket (C3 domain). Their $\mathrm{IC}_{50}$ values depend on the affinity of inhibitor and the amount of added ATP [22]. High sequence homology and structural similarity in the C3 
domain of PKC isozymes are major obstacles in the development of PKC isozyme-specific inhibitors [3].

\subsubsection{Indolocarbazole Compounds}

Several natural and biosynthetic indolocarbazole compounds have been identified, for example, staurosporine and its analogs such as Gö 6976, K252 compounds, 7-hydroxystaurosporine (UCN-01), and 4'- $\mathrm{N}$-benzoylstaurosporine (midostaurin) (for review see [23-26]) (Figure 3). Among the staurosporine analogs, clinical trials of UCN-01 and midostaurin have been broadly carried out.

I A

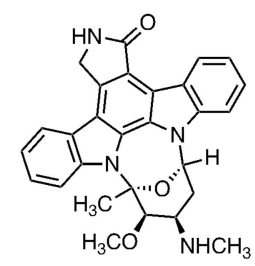

Staurosporine

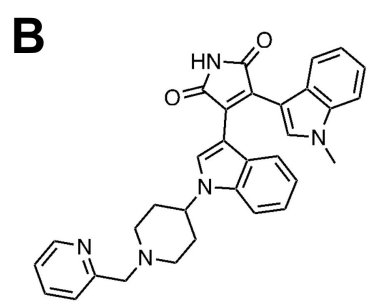

Enzastaurin (LY317615)<smiles>C=CC</smiles>

Chelerythrine

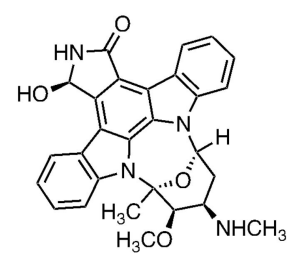

7-hydroxystaurosporine (UCN-01)

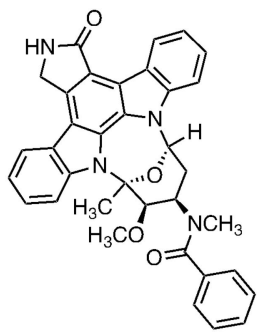

\section{4'-N-benzoylstaurosporine}

(Midostaurin)

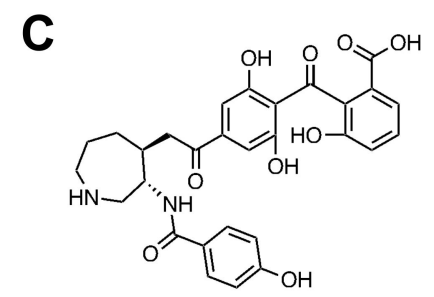

Sotrastaurin

(AEB071)<smiles>CN1CCN(c2nc(C3=C(c4c[nH]c5ccccc45)C(=O)NC3=O)c3ccccc3n2)CC1</smiles>

Ruboxistaurin (LY 333531)<smiles>Nc1nc2ccc(OC(F)(F)F)cc2s1</smiles>

Riluzole

Figure 3. I. Chemical structure of C3 domain-binding inhibitors (ATP competitive PKC inhibitors): (A) indolocarbazole compounds, (B) Maleimide-based inhibitors. Bisindolylmaleimide (Bis) compounds (enzastaurin and ruboxistaurin) and sotrastaurin, and (C) other ATP competitive PKC inhibitor. II. Chemical structure of C4 domain-binding inhibitors (substrate competitive PKC inhibitors).

Staurosporine (C3): Staurosporine is a compound produced by Streptomyces sp. with an $\mathrm{IC}_{50}$ value of $2.7 \mathrm{nM}$ for PKC and binds to its catalytic domain [27]. Its inhibitory activity increases in the following order: $\mathrm{cPKC}>\mathrm{nPKC}>\mathrm{aPKC}[28,29]$. Staurosporine also shows inhibitory activity against several serine/threonine protein kinases and tyrosine kinases [25]. However, there are no reports on the use of staurosporine in clinical trials.

UCN-01 (7-hydroxystaurosporine) (C3): UCN-01 is a compound isolated from Streptomyces sp. (strain N-126), and its stereoisomer is UCN-02 (7-epi-hydroxystaurosporine) [30,31]. The $\mathrm{IC}_{50}$ values of $\mathrm{UCN}-01$ and $\mathrm{UCN}-02$ are 4.1 and $62 \mathrm{nM}$, respectively [31]. Similar to staurosporine, UCN-01 inhibits PKC activity by binding to its catalytic domain [32] and exhibits significantly higher affinity toward cPKC than nPKC and aPKC $[28,29]$. The elimination half-lives of $\mathrm{UCN}-01$ after intravenous injection into mice, rats, and dogs were $3.00-3.98,4.02-4.46$, and $11.6 \mathrm{~h}$, respectively [33]. 
CN-01 inhibits the growth of cancer cells by blocking the cell cycle progression from G1 to $S$ phase that is important in regulating cell proliferation [34]. UCN-01-mediated inhibition of the G1 to $S$ phase transition is caused due to the reduction of cyclin-dependent kinase 1/2 (CDK1/2) [35-37], cyclin A [37], and checkpoint kinase 1/2 (CHK1/2) [38,39] as well as the induction of CDK inhibitors p21 and p27 [36,37].

Phase I trials of UCN-01 have been performed, in combination with prednisone, in patients with solid cancers and lymphomas [40], with irinotecan in patients with solid cancers [41], with perifosine in patients with relapsed and refractory acute leukemias and high-risk myelodysplastic syndrome [42], with fludarabine monophosphate in patients with relapsed lymphoma [43], with cisplatin in advanced solid tumors [44], with fluorouracil in patients with advanced solid tumors [45], and with carboplatin in advanced solid tumors [46]. However, several studies have shown no objective response [40-42,45].

Furthermore, Phase I/II clinical trials of UCN-01 have been performed in combination with irinotecan in patients with metastatic triple negative breast cancer (TNBC: negative for estrogen receptor, progesterone receptor, and HER2) [47,48]. Although impressive clinical activity was not obtained, a phase II study reported that effective CHK1 inhibition could enhance chemotherapy-induced apoptosis in TP53-mutant tumors [48]. Phase I/II studies of UCN-01 and topotecan were performed in patients with advanced ovarian cancer $[49,50]$, but significant clinical benefit was not observed in the phase II study [50]. No further clinical trials of UCN-01 have been conducted after these studies.

Midostaurin (4'-N-benzoylstaurosporine): Midostaurin (also known as PKC412; CGP 41251 ) is a staurosporine analog isolated from Streptomyces staurosporeus. Similar to staurosporine, midostaurin is an ATP-competitive inhibitor and inhibits multiple protein kinases. Although midostaurin has lower inhibitory activity for PKC, its specificity for PKC is higher compared with staurosporine [51,52]. Midostaurin treatment inhibits the growth of various cancer cells and reverses P-glycoprotein-mediated multidrug resistance of cancer cells by interfering with P-glycoprotein function [51,52].

FMS-like tyrosine kinase 3 (FLT3) mutations with internal tandem duplication (ITD) are associated with high leukemic burden and poor prognosis in patients with acute myeloid leukemia (AML) [53]. FLT3/ITD mutations stimulate the tyrosine kinase activity of FLT3, resulting in growth factor-independent proliferation of FLT3/ITD-mutant AML cells [53,54]. G1 arrest and apoptosis were observed in midostaurin-treated FLT3-mutant leukemia cells by direct inhibition of tyrosine kinase $\left(\mathrm{IC}_{50} \leq 10 \mathrm{nM}\right)$ [55]. In a recent phase III trial, the addition of midostaurin to standard chemotherapy significantly prolonged overall and event-free survival in mutant FLT3-positive AML patients [56].

Furthermore, systemic mastocytosis is a heterogeneous group of disorders caused by the abnormal accumulation of mast cells in organs, such as the bone marrow, liver, spleen, gastrointestinal tract, and skin. Most patients with systemic mastocytosis have an Asp816Val (D816V) mutation in the KIT receptor tyrosine kinase [57]. Midostaurin treatment significantly reduced the percentage of peripheral blood mast cells and serum histamine levels in patients with systemic mastocytosis through inhibition of KIT tyrosine kinase [58]. In addition, midostaurin induced apoptosis and downregulation of CD2 and CD63 [59] and inhibited IgE-dependent upregulation of CD63 in the mast cell leukemia cell line HMC-1 [60], resulting in enhanced inhibition of cell growth. A phase II trial showed significant clinical benefits in patients with advanced systemic mastocytosis after oral treatment with midostaurin $[61,62]$. However, no unexpected toxicity was observed with a median follow-up of 10 years after the phase II trial [61].

Midostaurin has been approved by the Food and Drug Administration (FDA) since April 2017 for the treatment of newly diagnosed adult AML patients with mutant FLT3positive or adult patients with systemic mastocytosis with associated hematological neoplasm, or mast cell leukemia (https: / www.fda.gov/drugs/resources-information-approveddrugs/midostaurin) (access on 10 September 2020). Midostaurin treatment indicated higher cost-effectiveness in mutant FLT3-positive adult AML patients compared to the standard of care in these patients [63]. In a phase II hypothesis-generating trial, the addition of mi- 
dostaurin to intensive chemotherapy increased event-free survival at 2 years by $39 \%$ (95\% confidence interval (CI), 33-47\%) and 34\% (95\% CI, 24-47\%) in younger and older patients, respectively, compared to historical controls treated within five prospective trials [64]. In addition, further clinical trials of midostaurin are in progress [65].

As a result, although midostaurin was originally developed as a PKC inhibitor, its success in clinical trials is mainly due to the inhibition of tyrosine kinase. However, it is not clear whether these midostaurin-induced positive results in AML patients are caused owing to inhibition of tyrosine kinase alone or both tyrosine kinase and PKC. Nevertheless, while it is true that midostaurin-mediated inhibition of tyrosine kinases is effective against AML, other tyrosine kinase inhibitors (e.g., gilteritinib and quizartinib) also show significantly improved clinical events in patients with FLT3-mutated AML [66,67].

\subsubsection{Maleimide-Based Inhibitors}

Bisindolylmaleimide (Bis) Compounds

Bis compounds are also synthetic analogs of staurosporine. Examples of typical compounds include Bis-1 (also known as GF 109203X or Gö 6850) [68], Bis-8 (Ro 31-7549) [69], Bis-9 (Ro 31-8220) [69], enzastaurin (LY317615) [70], and ruboxistaurin (LY 333531) [71]. While Bis-1, $-2,-3,-8,-9$, and -10 exhibit high inhibitory potential for PKC, they can also suppress other protein kinases $[68,69,72,73]$. However, Bis-4 and -5 exhibit little or no inhibition of PKC as well as several other protein kinases [72]. On the other hand, enzastaurin and ruboxistaurin are selective inhibitors of $P K C \beta[70,71]$ and have been extensively applied in clinical trials.

Enzastaurin (LY317615): Enzastaurin is an acyclic bisindolylmaleimide and an ATPcompetitive, selective inhibitor of $\mathrm{PKC} \beta$. The $\mathrm{IC}_{50}$ values were $6 \mathrm{nM}$ for PKC $\beta, 39 \mathrm{nM}$ for $\mathrm{PKC} \alpha, 83 \mathrm{nM}$ for PKC $\gamma$, and $110 \mathrm{nM}$ for PKC $\varepsilon$ in a cell-free assay [70]. Several studies have reported that enzastaurin induces antiproliferative and proapoptotic activity by inhibiting AKT and GSK3 $\beta$, a downstream target of the AKT pathway $[70,74-76]$, in addition to inhibiting PKC $\beta[76,77]$.

Despite its inhibitory effects on cancer cells, a phase II trial of enzastaurin in combination with bevacizumab [78] and a phase III trial of enzastaurin alone [79] showed no clear clinical benefit in patients with recurrent malignant gliomas. In a phase III trial of enzastaurin, patients with high-risk diffuse large B-cell lymphoma (DLBCL) received a daily dose of enzastaurin ( $500 \mathrm{mg}$ ) orally for 3 years, but no significant improvement in disease-free survival was observed [80].

Furthermore, in a phase II trial of enzastaurin, there were no significant clinical benefits in patients, with previously treated multiple myeloma [81], with brain metastasis after whole brain radiotherapy [82], with epithelial ovarian or primary peritoneal carcinoma [83], with relapsed or refractory mantle cell lymphoma [84], with metastatic breast cancer previously treated with an anthracycline- and a taxane-containing regimen [85], and with relapsed or refractory advanced cutaneous T-cell lymphoma [86].

In addition, several phase II studies of enzastaurin in combination with other anticancer drugs have been conducted in patients with various cancers, such as erlotinib or erlotinib / enzastaurin in patients with non-small-cell lung cancer (NSCLC) [87], temozolomide or temozolomide/enzastaurin plus radiation therapy in patients with glioblastoma multiforme and gliosarcoma [88], docetaxel/prednisone or docetaxel/prednisone/enzastaurin in patients with castration-resistant metastatic prostate cancer [89], paclitaxel/carboplatin or paclitaxel/carboplatin/enzastaurin in patients with advanced ovarian cancer [90], 5fluorouracil/leucovorin plus bevacizumab with or without enzastaurin in patients with metastatic colorectal cancer [91], pemetrexed or pemetrexed/enzastaurin in patients with advanced NSCLC [92], and gemcitabine or gemcitabine/enzastaurin in patients with advanced or metastatic pancreatic cancer [93]. However, these phase II trials failed to show any clinical benefits (e.g., progression-free survival) in these combinatorial treatments.

A phase I trial has also been conducted in children with recurrent central nervous system malignancies [94]. Despite the absence of objective responses, enzastaurin was well 
tolerated in children and the recommended phase II dose is $440 \mathrm{mg} / \mathrm{m}^{2} /$ day administered once, daily [94].

Ruboxistaurin (LY 333531): Ruboxistaurin, a macrocyclic bisindolylmaleimide compound, shows higher inhibitory activity for PKC $\beta 1\left(\mathrm{IC}_{50}=4.7 \mathrm{nM}\right)$ and $\mathrm{PKC} \beta 2\left(\mathrm{IC}_{50}=5.9 \mathrm{nM}\right)$, compared to other PKC isozymes, through ATP-dependent competitive inhibition [71].

PKC $\beta$ is highly expressed in the retina. Ruboxistaurin reduces the pathogenesis of diabetic retinopathy in diabetic rats by inhibiting PKC $\beta$ and hence preventing the increase in leukostasis and decrease in retinal blood flow $[95,96]$. In addition, it reduced the expression of endothelin-1 and platelet-derived growth factor in the retina [97] and inhibited vascular endothelial growth factor-induced phosphorylation of Akt and extracellular signal-regulated kinase $1 / 2$ [98].

Patients with diabetic nephropathy exhibit either a painless syndrome with loss of sensation or a painful disorder accompanied by hyperalgesia and allodynia [99,100]. Ruboxistaurin attenuates diabetic hyperalgesia in diabetic rats by reducing the neuronal nitric oxide synthase-cGMP system [101]. Ruboxistaurin also inhibits NADPH oxidasemediated production of reactive oxygen species in the kidney of diabetic rats, which is associated with renal injury [102]. Ruboxistaurin $(10 \mu \mathrm{M})$ binds to the ATP binding site of 3phosphoinositide dependent protein kinase-1 (PDK1), which is involved in the insulin-like growth factor signaling pathway, and exhibits higher inhibitory effects on PDK1, compared to other bisindolylmaleimides (each $10 \mu \mathrm{M}$ ), such as Bis-1, -2, -3, and -8 [73].

Transforming growth factor- $\beta$ (TGF- $\beta$ ) activation stimulates the phosphoinositide-3kinase/Akt pathway that accelerates renal injury and dysfunction [103]. Ruboxistaurin treatment reduces high glucose-induced Akt and TGF- $\beta$ activation in mesangial cells and Akt activation in the renal cortex of diabetic rats [104]. In addition, ruboxistaurin-treated rat models of diabetic nephropathy showed a significant decrease in osteopontin expression, in addition to macrophage infiltration, interstitial fibrosis, and TGF- $\beta$ activity in tubular epithelial cells of the cortex [105]. Based on these results, ruboxistaurin has been considered as a potential therapeutic agent for diabetic nephropathy and retinopathy.

A phase III study investigated the effect of ruboxistaurin ( $32 \mathrm{mg} /$ day) on vision loss in patients with moderate to severe non-proliferative diabetic retinopathy. Reduced occurrence of sustained moderate visual loss $(\geq 15$-letter decline in visual acuity sustained for the last 6 months of study participation) was observed in patients with greatest ruboxistaurin exposure ( $\sim 5$ years), compared to control patients ( 2-year ruboxistaurin exposure) [106]. Furthermore, two phase III trials of ruboxistaurin have been conducted in patients with (Early Treatment Diabetic Retinopathy Study) retinopathy level 20 to 47D or 35B to 53E, and no prior panretinal or focal photocoagulation in at least one eye at baseline. Although ruboxistaurin treatment showed an approximately 50\% reduction in sustained moderate vision loss, caused due to diabetic macular edema, statistical significance was not achieved [107]. For patients with diabetes and symptomatic diabetic peripheral neuropathy, two identical, phase III, parallel, randomized, double-blind, placebo-controlled trials of ruboxistaurin ( $32 \mathrm{mg}$ /day) have been performed, but these trials failed to show a significant and progressive improvement in symptoms [108]. Based on these findings, ruboxistaurin has not been used for further clinical trials.

\section{Sotrastaurin}

Sotrastaurin \{AEB071; 3-(1H-indol-3-yl)-4-[2-(4-methylpiperazin-1-yl) quinazolin-4-yl] pyrrole-2,5-dione\} is a potent and selective pan-PKC inhibitor, with various $\mathrm{K}_{\mathrm{i}}$ values for PKC isozymes, such as $0.95 \mathrm{nM}$ for PKC $\alpha, 0.64 \mathrm{nM}$ for PKC $\beta, 0.22 \mathrm{nM}$ for PKC $\theta$, and 1.8-3.2 $\mathrm{mM}$ for $\mathrm{PKC} \delta, \varepsilon$, and $\eta[109,110]$. Sotrastaurin exhibits immunosuppressive functions, such as inhibition of T-cell activation [111] and suppression of B-cell antibody response [112]. Sotrastaurin has been reported to prevent T-cell-mediated rejection in liver and kidney transplantation [113]. The efficacy and safety of sotrastaurin alone in de novo kidney transplant recipients [114], sotrastaurin plus tacrolimus in de novo liver [115], and kidney transplant recipients [116], and sotrastaurin plus everolimus in de novo kidney 
transplant recipients [117] were evaluated through phase II clinical trials. All these clinical trials exhibited adverse effects and high failure rates with respect to efficacy.

Furthermore, sotrastaurin showed growth inhibitory effects on CD79-mutant DLBCL through NF- $\mathrm{kB}$ pathway inhibition and induction of $\mathrm{G}_{1}$-phase cell-cycle arrest and/or cell death $[118,119]$. However, a phase Ib study of safety and efficacy of sotrastaurin and everolimus (mTOR inhibitor) in patients with CD79-mutant or activated B-cell-like subtype DLBCL exhibited suboptimal tolerability of the combination treatment, resulting in no implementation of phase II (NCT01854606).

In addition, a recent phase I study of sotrastaurin in patients with metastatic uveal melanoma showed that it was well tolerated, and modest clinical activity was observed, with a low objective response rate (3\%) [120].

\subsubsection{Other ATP Competitive PKC Inhibitors}

Balanol (SPC 100840) was isolated from Verticillium balanoides and shows $\mathrm{IC}_{50}$ values of 4-9 $\mathrm{nM}$ for PKC $\beta 1, \beta 2, \gamma, \delta, \varepsilon$, and $\eta$ and $150 \mathrm{nM}$ for PKC $\zeta$ [121]. Several balanol analogs have also been synthesized [122-124]. For example, cyclopentane-based analogs of balanol are more potent PKC inhibitors than balanol alone [122,123].

Melittin (GIGAVLKVLTTGLPALISWIKRKRQQ) inhibits PKC activation with an IC $_{50}$ of $3 \mu \mathrm{M}$ [125] or $0.8 \mu \mathrm{M}$ [126] through direct interaction with the MgATP-sensitive binding domain $[125,127]$.

\subsection{C4 Domain (C-Lobe Domain)-Binding PKC Inhibitors (Substrate Competitive PKC Inhibitors)}

Pseudosubstrate-derived peptide inhibitors and mutant peptide inhibitors bind to the C4 domain of PKC. Some aPKC inhibitors (e.g., ICA- 1 and $\zeta$-Stat) also bind to the C4 domain.

\subsubsection{Peptide Inhibitors}

PKC peptide inhibitors are mainly divided into (1) peptides derived from PKC protein fragment and (2) peptides obtained by the mutation of phosphorylation sites of PKC substrates. Myristoylated (myr-PKC) inhibitors show higher inhibitory effects on target PKC isozymes than non-myristoylated PKC peptide inhibitors [128-131]. Moreover, D-type amino acids are used to increase the inhibitory efficiency of peptide inhibitors [131,132]. Furthermore, peptide length can influence the potency of peptide inhibitor. Reduction in peptide length leads to decreased potency of the inhibitor $[130,133]$.

PKC protein fragment-derived peptide inhibitors: As mentioned above, the regulatory region of PKCs contains an autoinhibitory pseudosubstrate domain that interacts with the $\mathrm{C} 4$ domain. These pseudosubstrate-derived peptides are used as selective and cell-permeable inhibitor of PKC, such as PKC $\alpha / \beta$ pseudosubstrate peptide (PKC19-36) (RFARKGALRQKNVHEVKN) and its derivative (FARKGALRQ) [128,133], PKC $\varepsilon$ pseudosubstrate peptide (ERMRPRKRQGAVRRRV) [134], and PKC $\zeta$ pseudosubstrate-derived $\zeta$-inhibitory peptide (ZIP; SIYRRGARRWRKL) [135]. Although these PKC protein fragmentderived peptide inhibitors are a useful tool for understanding the PKC-mediated signaling pathway, they may not be suitable as therapeutic agents because of their weak inhibitory abilities for PKC [2].

Furthermore, several peptide inhibitors have been synthesized for inhibiting the translocation of the target PKC isozyme. These peptides are mainly derived from variable regions, such as the PKC $\varepsilon$ V1 region-derived peptide (EAVSLKPT) [136], PKC $\alpha$ V5 regionderived peptide (QLVIAN) [137], PKC $\beta 1$ V5 region-derived peptide (KLFIMN) [138], PKC $\beta 2$ V5 region-derived peptide (QEVIRN) [138], and PKC $\delta$ V1 region-derived peptide (SFNSYELGSL) [139]. As an exception, PKC $\beta$ C2 region-derived peptides can also inhibit the translocation of $\mathrm{cPKC}$ isozymes. $\mathrm{PKC} \beta \mathrm{C} 2$ region-derived peptides, such as C2-1 (KQKTKTIK), C2-2 (MDPNGLSDPYVKL), and C2-4 (SLNPEWNET), inhibit the binding of PKC $\beta$ C2 fragment to RACK. These inhibitions block RACK activation-induced translocation of PKC $\beta$ and thereby decrease PKC $\beta$ translocation-mediated function [20,21]. 
However, these peptides show poor cellular membrane penetration which becomes a potential obstacle to their clinical application. For their efficient cytosolic delivery, the grafting of cell-penetrating peptides (e.g., human immunodeficiency virus (HIV-1) Tat) has been broadly used [136,139-141].

In a phase II clinical trial of PKC $\delta$ V1 region-derived peptide (also known as delcasertib or KAI-9803) [139], its intravenous injection into patients within $6 \mathrm{~h}$ of undergoing primary percutaneous coronary intervention for acute ST elevation myocardial infarction did not improve clinical events and left ventricular function and did not reduce expression of biomarkers of myocardial injury [140]. Furthermore, in a phase II clinical trial of PKC $\varepsilon$ V1 region-derived peptides (KAI-1678) [136], its subcutaneous injection, for the treatment of neuropathic pain, in patients with postherpetic neuralgia failed to show a significant reduction in pain intensity ([141].

Mutant peptide inhibitors: Mutant peptide inhibitors are generated by replacing the phosphorylation sites (Ser or Thr) with mostly Ala [130,142]. However, a study has reported that Cys replacement instead of Ala increases the potency of the inhibitor [129]. Mutant peptide inhibitors block the binding of the substrate to PKC. However, these mutant peptide inhibitors show very low inhibitory efficiencies for PKC [130].

\subsubsection{Other Inhibitors Binding to the $\mathrm{C} 4$ Domain}

Chelerythrine $\left(\mathrm{IC}_{50}=0.66 \mu \mathrm{M}\right)$, a natural benzophenanthridine alkaloid isolated from Chelidonium majus, is a competitive inhibitor with respect to the phosphate acceptor (histone IIIS) and a noncompetitive inhibitor with respect to ATP, meaning that it binds to the C4 domain of the PKC catalytic region [143]. It has broad biological activities, such as anticancer [144], anti-inflammatory [145], antiviral [146], antifungal [147], and antibacterial effects [148]. Chelerythrine inhibits the growth of cells in various ranges of $\mathrm{IC}_{50}$ values. For example, the $\mathrm{IC}_{50}$ of chelerythrine is $2.6-4.2 \mu \mathrm{M}$ for TNBC cell lines (MDA-MB-231, BT549, HCC1937 and MDA-MB-468) [149], >10 $\mu$ M for non-TNBC cell lines (MCF7, ZR-75-1, SK-BR-3 and MDA-MB-453) [149], 6.2 $\mu \mathrm{M}$ for HeLa cells [150], and 5.0-7.8 $\mu \mathrm{M}$ for NSCLC cell lines (HCC827, SK-MES-1, and A459) [151]. On the other hand, a study suggested that, while chelerythrine could not inhibit PKC activity, it could stimulate PKC activity in the cytosolic fractions of rat and mouse brain tissues at concentrations of up to $100 \mu \mathrm{M}$ [152].

Riluzole binds to the catalytic domain of PKC, but ATP concentrations do not affect riluzole-mediated PKC inhibition. This means that riluzole is not a competitive inhibitor of ATP and binds to the C4 domain [153]. Riluzole is an FDA-approved medication that has neuroprotective properties and is used to treat amyotrophic lateral sclerosis. PKC is activated in amyotrophic lateral sclerosis, and riluzole-mediated PKC inhibition may be involved in the neuroprotective mechanism [153,154]. Furthermore, riluzole $(0.1-10 \mu \mathrm{M})$ inhibits VEGF-stimulated PKC $\beta$ II activation and cell proliferation in bovine retinal endothelial cell and human umbilical vein endothelial cell cultures [155]. Riluzole (30 $\mu \mathrm{M})$ also inhibits PKC activity in the membrane of cortical cells [153].

HIV-1 Tat-peptide (aa 48-60), with an $\mathrm{IC}_{50}$ value of $22 \mathrm{nM}$ for PKC $\alpha$, competes with the kinase substrates, but not with ATP [156]. Furthermore, the inhibitor $1 \mathrm{H}$-imidazole4-carboxamide, 5-amino-1-[2,3-dihydroxy-4-[(phosphonooxy) methyl] cyclopentyl-[1R$(1 \mathrm{a}, 2 \mathrm{~b}, 3 \mathrm{~b}, 4 \mathrm{a})]$, binds to the $\mathrm{C} 4$ domain of PKC $\lambda / \mathrm{l}$, but not other PKCs [157]. Bis-1 is an ATP competitive inhibitor [68], but also a substrate competitive inhibitor that interferes with the binding of the pseudosubstrate domain to the substrate recognition site [158].

\section{Atypical PKC Inhibitors}

There are few reports on PKC isozyme-specific inhibitors, but some aPKC-specific inhibitors have recently been reported and are summarized below. These inhibitors block the activity of aPKC by binding to either the PB domain that exists at the N-terminus of aPKC or to the catalytic domain (Figure 1). The therapeutic efficacy of aPKC inhibitors in patients is yet to be investigated in clinical trials. 


\subsection{ZIP (PB Domain)}

While ZIP (SIYRRGARRWRKL) shows high binding affinity for aPKC, it can also bind to multiple PKC isozymes [135]. Its potential inhibitory activity for PKC $\mathrm{I}$ and $\mathrm{PKC} \zeta$ is nearly equal $\left(K_{i}(95 \% \mathrm{CI})=1.43\right.$ and $1.7 \mu \mathrm{M}$, respectively) [159]. ZIP does not inhibit the catalytic activity of the kinase domain of $\mathrm{PKC} \zeta$ but prevents the interaction of the PB1 domain of $\mathrm{PKC} \zeta$ with that of $\mathrm{p} 62$ by binding to an acidic surface on the PB1 domain of p62 [160,161].

$\mathrm{PKM} \zeta$, an $\mathrm{N}$-terminal truncated isoform of $\mathrm{PKC} \zeta$, plays a critical role in the maintenance of long-term potentiation, long-term memory, and chronic pain [159,162-164]. ZIP is a candidate inhibitor for PKM $\zeta$. Despite its dependence on substrate and kinase concentrations, myr-ZIP completely inhibits PKM $\zeta$ activity in the range of $5-10 \mu \mathrm{M}$ and its $\mathrm{IC}_{50}$ value for PKM $\zeta$ ranges from 0.076 to $2 \mu \mathrm{M}[135,159,163,165]$. On the other hand, ZIP-induced excitotoxic death of cultured neurons at 5-10 $\mu \mathrm{M}$ has been reported [166]. In animal disease models, ZIP administration alleviated or prevented pain-related disorders, such as chronic visceral pain [167] and neuropathic pain [168], and memory-related disorders, such as anxiety in autism [169] and fear-mediated anxiety [170,171]. However, there are no data on the application of ZIP inhibitor peptide in clinical trials.

\subsection{Auranofin and Sodium Aurothiomalate (PB1 Domain)}

Gold compounds, auranofin (Ridaura; 1-thio- $\beta$-D-glucopyranosatotriethylphosphine gold-2,3,4,6-tetraacetate) and sodium aurothiomalate (Myochrysine; gold sodium thiomalate) (Figure 4) exhibit immunosuppressive activity and have been used in the treatment of rheumatoid arthritis [172,173]. They also inhibit PKCı and PKC $\zeta$ signaling by selectively targeting the PB1 domain (Cys-69) of PKCᄂ [174] and the PB1 domain (Cys-68) of $\mathrm{PKC} \zeta$, respectively [175]. The binding of auranofin and sodium aurothiomalate to the PB1 domain blocks the interaction of PKCı and PKC $\zeta$ with their adaptors, Par6, p62, and MEK5 [174,175]. For example, the sodium aurothiomalate inhibits the binding of PB1 domain of PKC $\zeta$ and PKCı to Par6 with the $\mathrm{IC}_{50}$ values of 3 [175] and $1 \mu \mathrm{M}$ [176], respectively. The cytotoxicity activity $\left(\mathrm{IC}_{50}\right)$ of auranofin and sodium aurothiomalate is $\leq 10 \mu \mathrm{M}$ in sensitive cancer cells and $>40 \mu \mathrm{M}$ in non-sensitive cancer cells [177-179]. Sodium aurothiomalate-sensitive cancer cells express significantly higher PKCı levels than insensitive cancer cells [179].

The phase I study of aurothiomalate has been conducted in patients with PKCIoverexpressed cancers, such as advanced NSCLC, ovarian cancer, and pancreatic cancer [180]. A feasibility study for enrolling asymptomatic ovarian cancer patients with increased levels of CA-125 (10 patients) has also been carried out by oral administration of auranofin, which resulted in decreased levels of CA-125 in one patient [181]. Furthermore, a phase I/II clinical trial of auranofin (NCT01419691) has been conducted in patients with chronic lymphocytic leukemia, small lymphocytic and prolymphocytic lymphoma [182].

\subsection{ICA-1 (C4, C-Terminal Lobe Domain)}

ICA-1 ([4-(5-amino-4-carbamoylimidazol-1-yl)-2,3-dihydroxycyclopentyl] methyl dihydrogen phosphate) specifically inhibits PKCı but not PKC C [183]. Its binding pocket was identified in the C-lobe of the catalytic (kinase) domain $[183,184]$. ICA-1 inhibited the activity of PKCı for myelin basic protein (MBP) by $16 \%$ at $0.1 \mu \mathrm{M}, 25 \%$ at $1 \mu \mathrm{M}$, and $45 \%$ at $5 \mu \mathrm{M}$, and for phosphotransferase by $22.6 \%$ at $0.1 \mu \mathrm{M}, 53.5 \%$ at $1 \mu \mathrm{M}$, and $80.0 \%$ at $5 \mu \mathrm{M}$. However, it showed no effects on the activity of PKC $\zeta$ for MBP and phosphotransferase [183]. In an inhibitory study using the human neuroblastoma cell line BE(2)-C, ICA-1 and aurothiomalate reduced cell proliferation by $58 \%$ at $48 \mathrm{~h}$ with an $\mathrm{IC}_{50}$ value of 0.1 and $100 \mu \mathrm{M}$, respectively [183]. Although ICA-1-mediated reduction in cell proliferation in several cancer cells [183-185] or in cancer animal models [186] has been reported, there are no studies on its application in the clinical trials. 


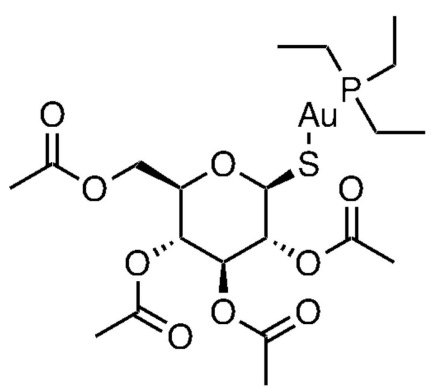

Auranofin (Ridaura)<smiles>O=S(=O)(O)c1cc(O)c2c(S(=O)(=O)O)cc(S(=O)(=O)O)cc2c1</smiles>

$\zeta$-Stat<smiles>[N+]OC(=O)C(CC(=O)O)S[AlH2]</smiles>

Sodium aurothiomalate<smiles>CC(=O)C1C(=O)CCC1=O</smiles>

ACPD<smiles>NC(=O)c1ncn(C2CC(CO)C(O)C2O)c1N</smiles>

ICA-1<smiles>Nc1c(S(=O)(=O)O)cc2cc(S(=O)(=O)O)ccc2c1N</smiles>

DNDA

Figure 4. Chemical structure of atypical PKC inhibitors. These inhibitors show high potential inhibitory activity for PKCı/ $\lambda$ (PKC $\lambda$ is the mouse homolog of PKC 1 ) and PKC $\zeta$.

\subsection{J-Stat (C4, C-Lobe)}

$\zeta$-Stat (8-hydroxy-1,3,6-naphthalenetrisulfonic acid) is regarded as a $\mathrm{PKC} \zeta$ specific inhibitor. Similar to ICA-1, its biding site exists in the C-lobe of the kinase domain [184]. When MBP was incubated with recombinant active PKC $\mathrm{l}$ and $\mathrm{PKC} \zeta$ in the presence of $\zeta$-Stat $(1-20 \mu \mathrm{M}), \zeta$-Stat showed $51 \%$ inhibition of PKC $\zeta$ at $5 \mu \mathrm{M}$, but only $13 \%$ inhibition of PKCᄂ at $20 \mu \mathrm{M}$ [184]. Recently, $\zeta-$ Stat was used to elucidate the signaling mechanisms of PKC $\zeta$-mediated growth, proliferation, and metastasis of cancer cells $[184,187,188]$.

\subsection{ACPD and DNDA (C4, C-Lobe; ACPD C3, N-Lobe for PKC- $\zeta)$}

ACPD (2-acetyl-1,3-cyclopentanedione) and DNDA (3,4-diaminonaphthalene-2,7disulfonic acid) bind to the catalytic domain of both PKCı and PKC $\zeta$ and inhibit both these kinases [189]. In more detail, ACPD interacts with amino acid residues 469-488 of the catalytic domain of PKC- - and amino acid residues 265-290 of PKC- $\zeta$. DNDA interacts with amino acid residues 339-395 of PKC-ı and amino acid residues 337-393 of PKC- $\zeta$ [189]. The $\mathrm{IC}_{50}$ value of ACPD and DNDA were approximately $2.5 \mu \mathrm{M}$, which was calculated based on their inhibitory effects on cell proliferation [187]. ACPD and DNDA can be used to inhibit aPKC-mediated cancer cell proliferation and for understanding the aPKC-mediated signaling transduction pathway [185,189-191].

\section{Antisense Oligonucleotides}

$\mathrm{PKC} \alpha$ is considered as a target for cancer treatment since it is overexpressed in many cancer cells [5,192]. A PKC $\alpha$-specific antisense oligonucleotide, aprinocarsen (ISIS3521/LY900003; a 20-base antisense oligonucleotide), has been applied in Phase II or/and III clinical trials in patients with recurrent high-grade astrocytomas [193], advanced NSCLC [194,195], advanced ovarian carcinoma [196], hormone-refractory prostate cancer [197], metastatic colorectal cancer [198], and previously treated low-grade non-Hodgkin's lymphoma (NHL) [199]. Unfortunately, however, aprinocarsen treatment with or without anticancer drugs failed to exhibit significant survival and other clinical benefit [193-199]. 


\section{PKC Activators}

C1 domain ligands are universally used for PKC activation, including bryostatin-1 and DAG and its analogues such as PDBu, phorbol 12-myristate 13-acetate (PMA; also known as 12-O-tetradecanoylphorbol-13-acetate (TPA)), and prostratin (13-O-acetyl-12deoxyphorbol) (Figure 5). Despite two phase I trials of PMA to identify its dose tolerance $[200,201]$, bryostatin- 1 is the most widely used agent in clinical trials.
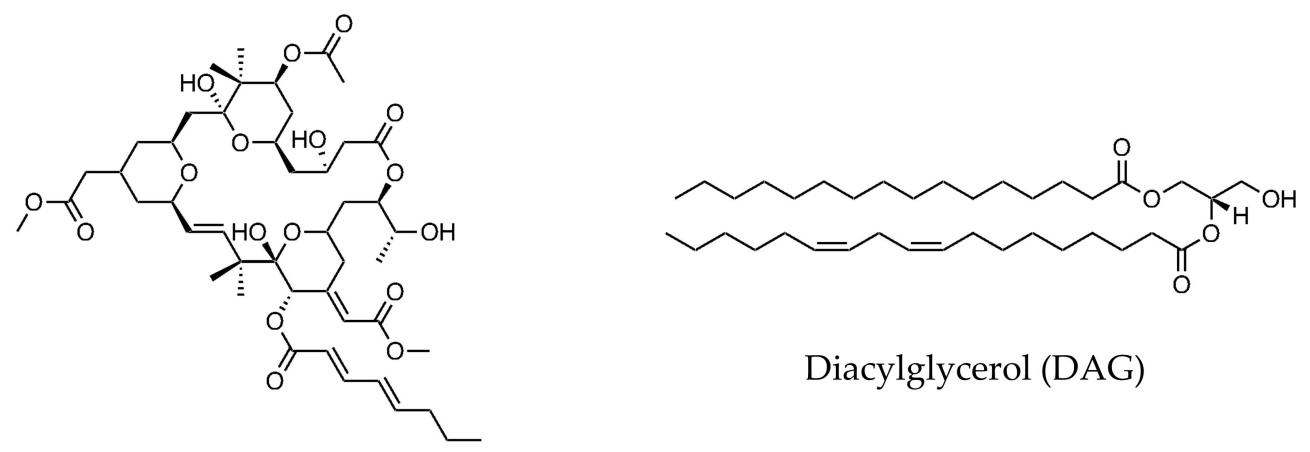

\section{Diacylglycerol (DAG)}

Bryostatin-1

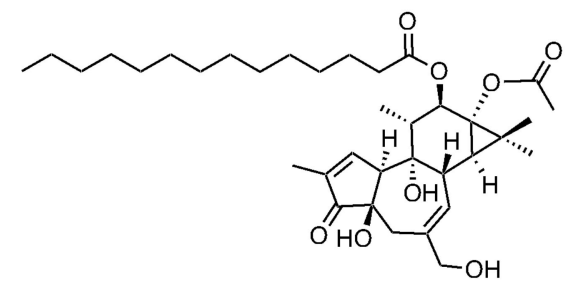

Phorbol 12-myristate 13-acetate (PMA)

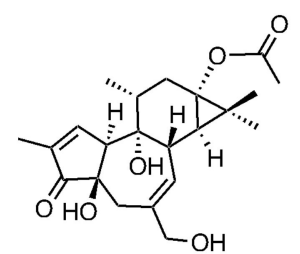

Prostratin (13-O-acetyl-12-deoxyphorbol)

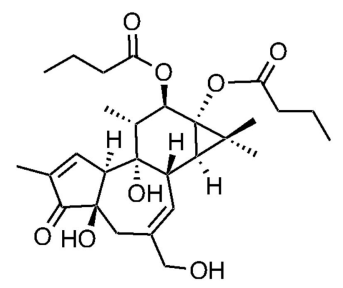

Phorbol 12,13-dibutyrate $(\mathrm{PDBu})$

Figure 5. Chemical structure of PKC activators (C1 domain-binding ligands).

\subsection{Bryostatin-1}

Bryostatin-1, a macrocyclic lactone isolated from a marine invertebrate, binds to the $\mathrm{C} 1$ domain of PKC and acts both as an activator and inhibitor for PKC. For example, short-term exposure to bryostatin-1 stimulates PKC activation, while long-term exposure promotes downregulation of PKC activity [202].

\subsubsection{Bryostatin-1 as a PKC Inhibitor}

Bryostatin-1 competes with cancer-promoting PKC ligands (e.g., DAG and phorbol esters) to bind to PKC since it has the same binding site (C1 domain) as PKC ligands. Based on these functions, phase II studies of bryostatin- 1 with other anticancer drugs have been performed in patients with various cancers. Phase II trials of single-agent bryostatin-1 showed no clinical effects in several cancers, such as metastatic malignant melanoma [203-205], metastatic renal cell carcinoma [206,207], metastatic colorectal cancer [208], NHL [209], relapsed multiple myeloma [210], advanced sarcoma and advanced head and neck cancer [211], metastatic or recurrent squamous cell carcinoma of the head and neck [212], squamous cell carcinoma of the cervix [213], and recurrent epithelial ovarian carcinoma [214].

Furthermore, no clinical responses were observed in phase II studies of bryostatin1/paclitaxel in patients with advanced pancreatic carcinoma [215], advanced NSCLC [216], and advanced or recurrent carcinoma of the cervix [217], as well as in a phase II study 
of four different doses of bryostatin-1/interleukin-2 treatment in patients with renal cell carcinoma [218].

On the other hand, bryostatin-1/paclitaxel treatment in a phase II study resulted in a superior response rate in patients with untreated, advanced gastric or gastroesophageal junction adenocarcinoma, compared to paclitaxel alone [219]. Another phase II study of the same treatment in patients with advanced esophageal cancer, despite potential anti-tumor activity, was prematurely closed because of excessive toxicity [220].

In patients with recurrent platinum-sensitive or resistant ovarian cancer, a phase II trial of bryostatin-1/cisplatin showed a modest response rate. However, it increased toxicity in platinum-pretreated patients [221]. A phase II study of bryostatin-1/vincristine showed efficacy in select patients (overall response rate of 31\%) with aggressive B-cell NHL which relapsed after autologous stem cell transplantation [222].

From the clinical studies mentioned above, the doses used in clinical trials of singleagent bryostatin- 1 ranged from 25 to $120 \mu \mathrm{g} / \mathrm{m}^{2}$ and from 25 to $65 \mu \mathrm{g} / \mathrm{m}^{2}$ in combination with other anticancer drugs. Interestingly, excessive toxicity was observed in patients treated with paclitaxel $\left(80-90 \mu \mathrm{g} / \mathrm{m}^{2}\right)$ plus bryostatin-1 $\left(40-50 \mu \mathrm{g} / \mathrm{m}^{2}\right)$ [220]. Furthermore, the combination of $45 \mu \mathrm{g} / \mathrm{m}^{2}$ bryostatin- 1 and $50 \mu \mathrm{g} / \mathrm{m}^{2}$ cisplatin showed increased toxicity in platinum-pretreated patients [221].

\subsubsection{Bryostatin-1 as a PKC Activator}

Previous studies have suggested that bryostatin-1- [223,224] or PMA- [225] mediated PKC $\varepsilon$ activation could reduce amyloid- $\beta$ levels and prevent learning and memory deficits in mice with AD. In a single-dose $\left(25 \mu \mathrm{g} / \mathrm{m}^{2}\right)$ phase IIa clinical trial, bryostatin- 1 administration to patients with $\mathrm{AD}$ showed cognitive improvement in the first 24 weeks through elevated PKC $\varepsilon$ levels [226]. A recent phase II study of bryostatin-1 (20 $\mu \mathrm{g})$ in patients with $\mathrm{AD}$ suggested that the primary endpoint at 13 weeks showed no significance for the full analysis set (FAS), but the improved signals of Severe Impairment Battery (SIB) scores were obtained at 13 weeks for the Completers Set and for both data sets (FAS + SIB) at 15 weeks, compared to those of placebo patients [227].

Furthermore, several studies showed that bryostatin-1-mediated PKC activation could reactivate latent (inactive) HIV-1 [228,229]. However, a phase I clinical trial of bryostatin-1 $\left(20 \mu \mathrm{g} / \mathrm{m}^{2}\right)$ in HIV-1infected patients exhibited no effect on PKC activity or on the transcription of latent HIV-1. These negative results may be due to low plasma concentrations of bryostatin-1 [230].

\section{Perspectives for Research and Application of PKC Inhibitors and Activators}

PKCs are regarded as attractive targets for cancer therapy because their hyperactivation in many cancers $[76,141,179,196]$. For these reasons, clinical trials of PKC inhibitors have focused on the treatment of many cancers. However, PKCs are also associated with various diseases, such as neurological diseases, cardiovascular diseases, and infection. Activators and inhibitors of PKC can be used for the treatment of these diseases.

PKC and AD: As briefly mentioned above, recently, PKC activation has been attracting attention as a novel therapeutic strategy for AD. For example, reduced $\mathrm{PKC} \varepsilon$ levels, but increased $\beta$-amyloid $(\mathrm{A} \beta)$ levels, were found in the hippocampus and temporal pole areas of patients with $\mathrm{AD}$ [231]. PKC $\varepsilon$ promotes the expression of brain-derived neurotrophic factor (BDNF) in the brain, which plays a role in the growth and maintenance of neuronal networks. However, reduced expression of PKC $\varepsilon$ and BDNF has been observed in the hippocampal neuron in patients with $\mathrm{AD}$ [224]. In fact, a phase IIa clinical trial showed that bryostatin-1-mediated activation of $\mathrm{PKC} \varepsilon$ could result in cognitive improvement in the first 24 weeks [226]. In addition, PKC $\alpha$ activation can be a useful tool for treating AD [232].

In contrast, aPKC activation promotes the phosphorylation of $\beta$-site amyloid precursor protein (APP)-cleaving enzyme 1 (BACE1) at Ser498, which increases the A $\beta$ generation during $A D$ pathogenesis [233]. Inhibition of aPKCs reduced the levels of $A \beta_{1-40 / 42}$ and phospho-tau in the brain of Het-M $\lambda \mathrm{KO}$ mice treated with insulin [234]. Furthermore, 
PKC $\delta$ inhibition reduces BACE1 expression, $\mathrm{A} \beta$ levels, and neuritic plaque formation, and rescues cognitive deficits in an APP Swedish mutations K594N/M595L/presenilin-1 with an exon 9 deletion-transgenic AD mouse model [235].

These results suggest that the biological function of $\mathrm{PKC}$ isozyme in AD progression could be different, and that PKC might be a therapeutic potential target for AD.

PKC and HIV: Recently, PKC activators have received attention as latency-reversing agents in HIV treatment. They reactivate latent HIV-1 within immune cells (e.g., CD4 and CD8 T cells) through activation of the NF- $\mathrm{kB}$ transcription factor pathway and enhance the recognition and removal of HIV by the immune system $[236,237]$. Despite the failure of a phase I clinical trial using the PKC activator bryostatin-1, which could be due to its low plasma concentrations [230], PKC activators are still regarded as one of the most promising agents for reversing HIV-1 latency. Therefore, PKC activators may remarkably increase therapeutic efficacy of HIV in combination with antiretroviral drugs [238,239].

PKC, cardiac disease, and heart failure: PKCs are good therapeutic targets for the treatment of cardiac disease and heart failure. For example, $\mathrm{PKC} \alpha, \mathrm{PKC} \beta, \mathrm{PKC} \delta$, and PKC $\varepsilon$ are targeted for treating cardiac hypertrophy, $\mathrm{PKC} \beta, \mathrm{PKC} \delta$, and $\mathrm{PKC} \varepsilon$ are targeted for treating heart failure, and PKC $\theta$ for lowing heart transplant rejection $[6,240,241]$. However, there are no reports regarding clinical trials of PKC activators or inhibitors for cardiac disease and heart failure, except phase I/II trials of delcasertib in patients with myocardial infarction [140,242].

\section{Summary and Overall Conclusions}

Activators and inhibitors of PKC and their applications in clinical trials are summarized in Table 1. Despite many clinical trials of PKC inhibitors in cancers, most of them showed no significant clinical benefits. On the other hand, a phase III trial of midostaurin plus standard chemotherapy in mutant FLT3-positive AML patients [56] and a phase II trial of midostaurin alone in patients with advanced systemic mastocytosis [61] exhibited significant clinical benefits, such as enhanced overall response rate, prolonged event-free survival, and low unexpected toxicity. These clinical benefits of midostaurin are mainly due to the inhibition of tyrosine kinase, but not PKC, as mentioned above. Further studies are needed to investigate whether these midostaurin-induced clinical benefits are caused by inhibition of tyrosine kinase alone or both tyrosine kinase and PKC. However, PKC inhibitors may increase clinical efficacy in combination with tyrosine kinase inhibitors.

Table 1. Activators and inhibitors of protein kinase $C(P K C)$ and their applications in clinical trials.

\begin{tabular}{ccccc}
\hline Diseases & $\begin{array}{c}\text { PKC Activators or } \\
\text { Inhibitors/Other Agents }\end{array}$ & Phases & Clinical Benefits & References \\
\hline Cancer & UCN-01/irinotecan & II & No significant clinical benefits \\
\hline $\begin{array}{c}\text { Metastatic triple negative breast } \\
\text { cancer }\end{array}$ & UCN-01/topotecan & II & No significant clinical benefits \\
\hline $\begin{array}{c}\text { Advanced ovarian cancer } \\
\text { [51] }\end{array}$ & III & $\begin{array}{c}\text { Significantly prolonged overall } \\
\text { and event-free survival }\end{array}$ \\
\hline $\begin{array}{c}\text { Midostaurin/standard } \\
\text { chemotherapy }\end{array}$ & Midostaurin & II & $\begin{array}{c}\text { Significant clinical benefits and } \\
\text { no unexpected toxicity }\end{array}$ \\
\hline $\begin{array}{c}\text { Advanced systemic mastocytosis } \\
\text { [61] }\end{array}$ & Enzastaurin (LY317615) & III & $\begin{array}{c}\text { No significant clinical benefits } \\
\text { [80] }\end{array}$ \\
\hline $\begin{array}{c}\text { High-risk diffuse large B-cell } \\
\text { lymphoma }\end{array}$ & & &
\end{tabular}


Table 1. Cont.

\begin{tabular}{|c|c|c|c|c|}
\hline Diseases & $\begin{array}{c}\text { PKC Activators or } \\
\text { Inhibitors/Other Agents }\end{array}$ & Phases & Clinical Benefits & References \\
\hline $\begin{array}{l}\text { Multiple myeloma, lung cancer with } \\
\text { brain metastases, epithelial ovarian or } \\
\text { primary peritoneal carcinoma, } \\
\text { metastatic breast cancer, and relapsed } \\
\text { or refractory mantle cell lymphoma } \\
\text { and advanced cutaneous T-cell } \\
\text { lymphoma }\end{array}$ & Enzastaurin & II & No significant clinical benefits & [81-86] \\
\hline Advanced non-small-cell lung cancer & Enzastaurin/erlotinib & II & No significant clinical benefits & [87] \\
\hline $\begin{array}{l}\text { Glioblastoma multiforme and } \\
\text { gliosarcoma }\end{array}$ & $\begin{array}{l}\text { Enzastaurin/temozolomide } \\
\quad+\text { radiation therapy }\end{array}$ & II & No significant clinical benefits & [88] \\
\hline $\begin{array}{c}\text { Castration-resistant metastatic } \\
\text { prostate cancer }\end{array}$ & $\begin{array}{c}\text { Enzastaurin/docetaxel + } \\
\text { prednisone }\end{array}$ & II & No significant clinical benefits & [89] \\
\hline Advanced ovarian cancer & $\begin{array}{l}\text { Enzastaurin/paclitaxel + } \\
\text { carboplatin }\end{array}$ & II & No significant clinical benefits & {$[90]$} \\
\hline Metastatic colorectal cancer & $\begin{array}{l}\text { Enzastaurin } / 5- \\
\text { fluorouracil + leucovorin }+ \\
\text { bevacizumab }\end{array}$ & II & No significant clinical benefits & [91] \\
\hline Advanced non-small cell lung cancer & Enzastaurin/pemetrexed & II & No significant clinical benefits & [92] \\
\hline $\begin{array}{l}\text { Advanced or metastatic pancreatic } \\
\text { cancer }\end{array}$ & Enzastaurin/gemcitabine & II & No significant clinical benefits & [93] \\
\hline $\begin{array}{l}\text { Metastatic malignant melanoma, renal } \\
\text { cell carcinoma, and colorectal cancer, } \\
\text { non-Hodgkin's lymphoma, relapsed } \\
\text { multiple myeloma, advanced sarcoma } \\
\text { and advanced head and neck cancer, } \\
\text { metastatic or recurrent squamous cell } \\
\text { carcinoma of the head and neck, } \\
\text { squamous cell carcinoma of the cervix, } \\
\text { and recurrent epithelial ovarian } \\
\text { carcinoma }\end{array}$ & Bryostatin-1 & II & No significant clinical benefits & {$[205-214]$} \\
\hline $\begin{array}{l}\text { Advanced pancreatic carcinoma, } \\
\text { non-small cell lung cancer, and } \\
\text { esophageal cancer, advanced or } \\
\text { recurrent carcinoma of the cervix, and } \\
\text { advanced gastric or gastroesophageal } \\
\text { junction adenocarcinoma }\end{array}$ & Bryostatin-1/paclitaxel & II & No significant clinical benefits & $\begin{array}{l}{[215-217,} \\
219,220]\end{array}$ \\
\hline Renal cell carcinoma & Bryostatin-1/interleukin-2 & II & No significant clinical benefits & [218] \\
\hline $\begin{array}{l}\text { Recurrent platinum-sensitive or } \\
\text { resistant ovarian cancer }\end{array}$ & Bryostatin-1/cisplatin & II & $\begin{array}{l}\text { Modest response rate but high } \\
\text { toxicity in platinum-pretreated } \\
\text { patients }\end{array}$ & [221] \\
\hline $\begin{array}{c}\text { Aggressive B-cell non-Hodgkin } \\
\text { lymphoma relapsing after autologous } \\
\text { stem cell transplantation }\end{array}$ & Bryostatin-1/vincristine & II & $\begin{array}{l}\text { Overall response rate of } 31 \% \\
\text { (efficacy in select patients) }\end{array}$ & [222] \\
\hline \multicolumn{5}{|l|}{ Diabetic retinopathy and neuropathy } \\
\hline $\begin{array}{l}\text { Moderate to severe non-proliferative } \\
\text { diabetic retinopathy }\end{array}$ & Ruboxistaurin (LY 333531) & III & $\begin{array}{c}\text { Reduced occurrence of } \\
\text { sustained moderate vision loss } \\
\text { but not significant }\end{array}$ & [106] \\
\hline $\begin{array}{l}\text { Diabetic retinopathy (retinopathy } \\
\text { level } 20 \text { to } 47 \mathrm{D} \text { or } 35 \mathrm{~B} \text { to 53E) }\end{array}$ & Ruboxistaurin & III & $\begin{array}{l}\text { Approximately } 50 \% \text { reduction } \\
\text { of sustained moderate vision } \\
\text { loss but not significant }\end{array}$ & [107] \\
\hline
\end{tabular}


Table 1. Cont.

\begin{tabular}{|c|c|c|c|c|}
\hline Diseases & $\begin{array}{c}\text { PKC Activators or } \\
\text { Inhibitors/Other Agents }\end{array}$ & Phases & Clinical Benefits & References \\
\hline $\begin{array}{l}\text { Diabetes and symptomatic diabetic } \\
\text { peripheral neuropathy }\end{array}$ & Ruboxistaurin & III & $\begin{array}{l}\text { No significant and progressive } \\
\text { improvement in symptoms }\end{array}$ & [108] \\
\hline \multicolumn{5}{|l|}{ Neurological diseases } \\
\hline \multirow[t]{2}{*}{ Alzheimer's disease } & Bryostatin-1 & IIa & $\begin{array}{l}\text { Cognitive improvement in the } \\
\text { first } 24 \text { weeks }\end{array}$ & [226] \\
\hline & Bryostatin-1 & II & $\begin{array}{l}\text { Improved the full analysis set } \\
\text { and the Severe Impairment } \\
\text { Battery scores at } 15 \text { weeks }\end{array}$ & [227] \\
\hline Postherpetic neuralgia & KAI-1678 & II & $\begin{array}{l}\text { No significant reduction in } \\
\text { pain intensity }\end{array}$ & [141] \\
\hline \multicolumn{5}{|l|}{ Transplant rejection } \\
\hline De novo kidney transplantation & Sotrastaurin (AEB071) & II & $\begin{array}{l}\text { Low efficacy and high adverse } \\
\text { events }\end{array}$ & [114] \\
\hline De novo kidney transplantation & Sotrastaurin/tacrolimus & II & $\begin{array}{l}\text { Limited benefits over standard } \\
\text { immunosuppressive therapy } \\
\text { and high adverse events }\end{array}$ & [116] \\
\hline De novo kidney transplantation & Sotrastaurin/everolimus & II & $\begin{array}{l}\text { High efficacy failure rates and } \\
\text { adverse events }\end{array}$ & [117] \\
\hline De novo liver transplantation & Sotrastaurin/tacrolimus & II & $\begin{array}{l}\text { High efficacy failure rates and } \\
\text { adverse events }\end{array}$ & [115] \\
\hline \multicolumn{5}{|l|}{ Cardiovascular diseases } \\
\hline Myocardial infarction & Delcasertib (KAI-9803) & II & No significant clinical benefits & [140] \\
\hline \multicolumn{5}{|l|}{ Infections } \\
\hline $\begin{array}{l}\text { Human immunodeficiency virus } \\
\text { (HIV) infection }\end{array}$ & Bryostatin-1 & I & $\begin{array}{l}\text { No effect on the transcription } \\
\text { of latent HIV-1 }\end{array}$ & [230] \\
\hline
\end{tabular}

The reason why PKC-targeted inhibitors show no significant clinical benefits in several clinical trials of cancers is not clear yet. However, we speculate that the following three possibilities might contribute to little or no clinical benefits in clinical trials of PKC inhibitors:

(1) Isozyme-nonspecific PKC inhibitors. PKC isozymes are involved in multiple biological functions in cancer cells, such as tumorigenic or anti-tumorigenic, pro-apoptotic or anti-apoptotic, and pro-proliferative or anti-proliferative [243,244]. Isozyme-nonspecific PKC inhibitors, especially, ATP competitive PKC inhibitors, can block the activation of PKC isozymes with both tumorigenic, anti-apoptotic, and pro-proliferative function as well as anti-tumorigenic, pro-apoptotic, and anti-proliferative function. Therefore, the use of isozyme-nonspecific PKC inhibitors as chemotherapy drugs could lead to decreased therapeutic efficacy in cancers.

(2) PKC mutations. PKC loss-of-function mutations are found in a multitude of cancers $[2,244]$. This suggests that PKC inhibitors fail to exhibit significant clinical benefits in patients with PKC-mutated cancers. However, there are no reports that show whether PKC mutations in cancers have been investigated in clinical trials of PKC inhibitors.

(3) Limitation of PKC as therapeutic target. PKCs related to pro-proliferative and anti-apoptotic function are significantly activated in cancers. Although the activation of these PKCs is inhibited by PKC inhibitors, other cellular signals (e.g., AKT) that are pro-proliferative and anti-apoptotic in cancer may be substituted for PKCs. On the other hand, certain inhibitors of PI3Ks that are upstream of PKCs and AKT show significant clinical benefits in cancer treatment [245-247]. 
Therefore, so long as cellular signals that have similar functions as PKCs are activated in cancers, the inhibition of PKC alone may result in little or no clinical benefits in clinical trials. In fact, accumulating evidence suggests that there is a limitation to design a cancer therapeutic strategy targeting PKC alone (Table 1).

Author Contributions: M.M. and J.-H.K.: Conceptualization, supervision, and writing-review and editing; T.K. and J.-H.K.: writing-original draft preparation; J.I. and M.E.: writing-review and editing. All authors have read and agreed to the published version of the manuscript.

Funding: This work was supported by JSPS KAKENHI grant numbers 19K09692 and 19H04488 and the Japan Agency for Medical Research and Development (AMED) under Grant Number JP21hm0102067.

Institutional Review Board Statement: Not applicable.

Informed Consent Statement: Not applicable.

Data Availability Statement: Not applicable.

Conflicts of Interest: The authors declare no conflict of interest.

\section{References}

1. Newton, A.C. Protein kinase C: Structural and spatial regulation by phosphorylation, cofactors, and macromolecular interactions. Chem. Rev. 2001, 101, 2353-2364. [CrossRef]

2. Newton, A.C. Protein kinase C: Perfectly balanced. Crit. Rev. Biochem. Mol. Biol. 2018, 53, 208-230. [CrossRef]

3. Steinberg, S.F. Structural basis of protein kinase C isoform function. Physiol. Rev. 2008, 88, 1341-1378. [CrossRef]

4. Kang, J.H.; Toita, R.; Kim, C.W.; Katayama, Y. Protein kinase C (PKC) isozyme-specific substrates and their design. Biotechnol. Adv. 2012, 30, 1662-1672. [CrossRef]

5. Kang, J.H. Protein kinase c (PKC) isozymes and cancer. New J. Sci. 2014, 2014, 231418. [CrossRef]

6. Marrocco, V.; Bogomolovas, J.; Ehler, E.; Dos Remedios, C.G.; Yu, J.; Gao, C.; Lange, S. PKC and PKN in heart disease. J. Mol. Cell. Cardiol. 2019, 128, 212-226. [CrossRef] [PubMed]

7. Geribaldi-Doldán, N.; Gómez-Oliva, R.; Domínguez-García, S.; Nunez-Abades, P.; Castro, C. Protein kinase C: Targets to regenerate brain injuries? Front. Cell Dev. Biol. 2019, 7, 39. [CrossRef] [PubMed]

8. Lamark, T.; Perander, M.; Outzen, H.; Kristiansen, K.; Øvervatn, A.; Michaelsen, E.; Bjørkøy, G.; Johansen, T. Interaction codes within the family of mammalian Phox and Bem1p domain-containing proteins. J. Biol. Chem. 2003, 278, 34568-34581. [CrossRef] [PubMed]

9. Hirano, Y.; Yoshinaga, S.; Ogura, K.; Yokochi, M.; Noda, Y.; Sumimoto, H.; Inagaki, F. Solution structure of atypical protein kinase C PB1 domain and its mode of interaction with ZIP/p62 and MEK5. J. Biol. Chem. 2004, 279, 31883-31890. [CrossRef] [PubMed]

10. Kobayashi, E.; Nakano, H.; Morimoto, M.; Tamaoki, T. Calphostin C (UCN-1028C), a novel microbial compound, is a highly potent and specific inhibitor of protein kinase C. Biochem. Biophys. Res. Commun. 1989, 159, 548-553. [CrossRef]

11. Shimamoto, Y.; Shimamoto, H.; Kwan, C.Y.; Daniel, E.E. Differential effects of putative protein kinase C inhibitors on contraction of rat aortic smooth muscle. Am. J. Physiol. 1993, 264, H1300-H1306. [CrossRef]

12. Sullivan, J.P.; Connor, J.R.; Shearer, B.G.; Burch, R.M. NPC 15437 interacts with the $\mathrm{C} 1$ domain of protein kinase C. An analysis using mutant PKC constructs. FEBS Lett. 1991, 285, 120-123. [CrossRef]

13. Sullivan, J.P.; Connor, J.R.; Tiffany, C.; Shearer, B.G.; Burch, R.M. 2,6-Diamino-N-([1-oxotridecyl)-2-piperidinyl]methyl)hexanamide (NPC 15437): A selective inhibitor of protein kinase C. Agents Act. 1991, 34, 142-144. [CrossRef]

14. Roaten, J.B.; Kazanietz, M.G.; Caloca, M.J.; Bertics, P.J.; Lothstein, L.; Parrill, A.L.; Israel, M.; Sweatman, T.W. Interaction of the novel anthracycline antitumor agent $\mathrm{N}$-benzyladriamycin-14-valerate with the $\mathrm{C} 1$-regulatory domain of protein kinase $\mathrm{C}$ : Structural requirements, isoform specificity, and correlation with drug cytotoxicity. Mol. Cancer Ther. 2002, 1, 483-492. [PubMed]

15. Slater, S.J.; Seiz, J.L.; Cook, A.C.; Stagliano, B.A.; Buzas, C.J. Inhibition of protein kinase C by resveratrol. Biochim. Biophys. Acta 2003, 1637, 59-69. [CrossRef]

16. Sachs, C.W.; Safa, A.R.; Harrison, S.D.; Fine, R.L. Partial inhibition of multidrug resistance by safingol is independent of modulation of P-glycoprotein substrate activities and correlated with inhibition of protein kinase C. J. Biol. Chem. 1995, 270, 26639-26648. [CrossRef]

17. Schwartz, G.K.; Ward, D.; Saltz, L.; Casper, E.S.; Spiess, T.; Mullen, E.; Woodworth, J.; Venuti, R.; Zervos, P.; Storniolo, A.M.; et al. A pilot clinical/pharmacological study of the protein kinase C-specific inhibitor safingol alone and in combination with doxorubicin. Clin. Cancer Res. 1997, 3, 537-543.

18. Dickson, M.A.; Carvajal, R.D.; Merrill, A.H., Jr.; Gonen, M.; Cane, L.M.; Schwartz, G.K. A phase I clinical trial of safingol in combination with cisplatin in advanced solid tumors. Clin. Cancer Res. 2011, 17, 2484-2492. [CrossRef]

19. Farah, C.A.; Sossin, W.S. The role of C2 domains in PKC signaling. Adv. Exp. Med. Biol. 2012, 740, 663-683. [CrossRef] 
20. Ron, D.; Luo, J.; Mochly-Rosen, D. C2 region-derived peptides inhibit translocation and function of $\beta$ protein kinase C in vivo. J. Biol. Chem. 1995, 270, 24180-24187. [CrossRef]

21. Zhang, Z.H.; Johnson, J.A.; Chen, L.; El-Sherif, N.; Mochly-Rosen, D.; Boutjdir, M. C2 region-derived peptides of $\beta$-protein kinase C regulate cardiac $\mathrm{Ca}^{2+}$ channels. Circ. Res. 1997, 80, 720-729. [CrossRef]

22. Knight, Z.A.; Shokat, K.M. Features of selective kinase inhibitors. Chem. Biol. 2005, 12, 621-637. [CrossRef]

23. Goekjian; Jirousek, M.R. Protein kinase $C$ in the treatment of disease: Signal transduction pathways, inhibitors, and agents in development. Curr. Med. Chem. 1999, 6, 877-903. [CrossRef]

24. Sánchez, C.; Méndez, C.; Salas, J.A. Indolocarbazole natural products: Occurrence, biosynthesis, and biological activity. Nat. Prod. Rep. 2006, 23, 1007-1045. [CrossRef]

25. Nakano, H.; Ōmura, S. Chemical biology of natural indolocarbazole products: 30 years since the discovery of staurosporine. $J$. Antibiot. 2009, 62, 17-26. [CrossRef] [PubMed]

26. Park, B.S.; Abdel-Azeem, A.Z.; Al-Sanea, M.M.; Yoo, K.H.; Tae, T.S.; Lee, S. Staurosporine analogues from microbial and synthetic sources and their biological activities. Curr. Med. Chem. 2013, 20, 3872-3902. [CrossRef] [PubMed]

27. Tamaoki, T.; Nomoto, H.; Takahashi, I.; Kato, Y.; Morimoto, M.; Tomita, F. Staurosporine, a potent inhibitor of phospholipid/Ca ${ }^{++}$ dependent protein kinase. Biochem. Biophys. Res. Commun. 1986, 135, 397-402. [CrossRef]

28. Seynaeve, C.M.; Kazanietz, M.G.; Blumberg, P.M.; Sausville, E.A.; Worland, P.J. Differential inhibition of protein kinase C isozymes by UCN-01, a staurosporine analogue. Mol. Pharmacol. 1994, 45, 1207-1214.

29. Mizuno, K.; Noda, K.; Ueda, Y.; Hanaki, H.; Saido, T.C.; Ikuta, T.; Kuroki, T.; Tamaoki, T.; Hirai, S.; Osada, S.; et al. UCN-01, an anti-tumor drug, is a selective inhibitor of the conventional PKC subfamily. FEBS Lett. 1995, 359, 259-261. [CrossRef]

30. Takahashi, I.; Asano, K.; Kawamoto, I.; Tamaoki, T.; Nakano, H. UCN-01 and UCN-02, new selective inhibitors of protein kinase C. I. Screening, producing organism and fermentation. J. Antibiot. 1989, 42, 564-570. [CrossRef] [PubMed]

31. Takahashi, I.; Saitoh, Y.; Yoshida, M.; Sano, H.; Nakano, H.; Morimoto, M.; Tamaoki, T. UCN-01 and UCN-02, new selective inhibitors of protein kinase C. II. Purification, physico-chemical properties, structural determination and biological activities. J. Antibiot. 1989, 42, 571-576. [CrossRef]

32. Takahashi, I.; Kobayashi, E.; Nakano, H.; Murakata, C.; Saitoh, H.; Suzuki, K.; Tamaoki, T. Potent selective inhibition of 7-O-methyl UCN-01 against protein kinase C. J. Pharmacol. Exp. Ther. 1990, 255, 1218-1221.

33. Kurata, N.; Kuwabara, T.; Tanii, H.; Fuse, E.; Akiyama, T.; Akinaga, S.; Kobayashi, H.; Yamaguchi, K.; Kobayashi, S. Pharmacokinetics and pharmacodynamics of a novel protein kinase inhibitor, UCN-01. Cancer Chemother. Pharmacol. 1992, $44,12-18$. [CrossRef] [PubMed]

34. Seynaeve, C.M.; Stetler-Stevenson, M.; Sebers, S.; Kaur, G.; Sausville, E.A.; Worland, P.J. Cell cycle arrest and growth inhibition by the protein kinase antagonist UCN-01 in human breast carcinoma cells. Cancer Res. 1993, 53, 2081-2086.

35. Wang, Q.; Worland, P.J.; Clark, J.L.; Carlson, B.A.; Sausville, E.A. Apoptosis in 7-hydroxystaurosporine-treated T lymphoblasts correlates with activation of cyclin-dependent kinases 1 and 2. Cell Growth Differ. 1995, 6, 927-936. [PubMed]

36. Akiyama, T.; Yoshida, T.; Tsujita, T.; Shimizu, M.; Mizukami, T.; Okabe, M.; Akinaga, S. G1 phase accumulation induced by UCN01 is associated with dephosphorylation of $\mathrm{Rb}$ and CDK2 proteins as well as induction of CDK inhibitor p21/Cip1/WAF1/Sdi1 in p53-mutated human epidermoid carcinoma A431 cells. Cancer Res. 1997, 57, 1495-1501.

37. Sugiyama, K.; Akiyama, T.; Shimizu, M.; Tamaoki, T.; Courage, C.; Gescher, A.; Akinaga, S. Decrease in susceptibility toward induction of apoptosis and alteration in G1 checkpoint function as determinants of resistance of human lung cancer cells against the antisignaling drug UCN-01 (7-Hydroxystaurosporine). Cancer Res. 1999, 59, 4406-4412. [PubMed]

38. Busby, E.C.; Leistritz, D.F.; Abraham, R.T.; Karnitz, L.M.; Sarkaria, J.N. The radiosensitizing agent 7-hydroxystaurosporine (UCN-01) inhibits the DNA damage checkpoint kinase hChk1. Cancer Res. 2000, 60, 2108-2112.

39. Graves, P.R.; Yu, L.; Schwarz, J.K.; Gales, J.; Sausville, E.A.; O'Connor, P.M.; Piwnica-Worms, H. The Chk1 protein kinase and the Cdc25C regulatory pathways are targets of the anticancer agent UCN-01. J. Biol. Chem. 2000, 275, 5600-5605. [CrossRef]

40. Kummar, S.; Gutierrez, M.E.; Gardner, E.R.; Figg, W.D.; Melillo, G.; Dancey, J.; Sausville, E.A.; Conley, B.A.; Murgo, A.J.; Doroshow, J.H. A phase I trial of UCN-01 and prednisone in patients with refractory solid tumors and lymphomas. Cancer Chemother. Pharmacol. 2010, 65, 383-389. [CrossRef]

41. Jimeno, A.; Rudek, M.A.; Purcell, T.; Laheru, D.A.; Messersmith, W.A.; Dancey, J.; Carducci, M.A.; Baker, S.D.; Hidalgo, M.; Donehower, R.C. Phase I and pharmacokinetic study of UCN-01 in combination with irinotecan in patients with solid tumors. Cancer Chemother. Pharmacol. 2008, 61, 423-433. [CrossRef]

42. Gojo, I.; Perl, A.; Luger, S.; Baer, M.R.; Norsworthy, K.J.; Bauer, K.S.; Tidwell, M.; Fleckinger, S.; Carroll, M.; Sausville, E.A. Phase I study of UCN-01 and perifosine in patients with relapsed and refractory acute leukemias and high-risk myelodysplastic syndrome. Investig. New Drugs 2013, 31, 1217-1227. [CrossRef]

43. Marti, G.E.; Stetler-Stevenson, M.; Grant, N.D.; White, T.; Figg, W.D.; Tohnya, T.; Jaffe, E.S.; Dunleavy, K.; Janik, J.E.; Steinberg, S.M.; et al. Phase I trial of 7-hydroxystaurosporine and fludararbine phosphate: In vivo evidence of 7-hydroxystaurosporine induced apoptosis in chronic lymphocytic leukemia. Leuk. Lymphoma 2011, 52, 2284-2292. [CrossRef] [PubMed]

44. Lara, P.N., Jr.; Mackm, P.C.; Synold, T.; Frankel, P.; Longmate, J.; Gumerlock, P.H.; Doroshow, J.H.; Gandara, D.R. The cyclindependent kinase inhibitor UCN-01 plus cisplatin in advanced solid tumors: A California cancer consortium phase I pharmacokinetic and molecular correlative trial. Clin. Cancer Res. 2005, 11, 4444-4450. [CrossRef] [PubMed] 
45. Kortmansky, J.; Shah, M.A.; Kaubisch, A.; Weyerbacher, A.; Yi, S.; Tong, W.; Sowers, R.; Gonen, M.; O'reilly, E.; Kemeny, N.; et al. Phase I trial of the cyclin-dependent kinase inhibitor and protein kinase $\mathrm{C}$ inhibitor 7-hydroxystaurosporine in combination with fluorouracil in patients with advanced solid tumors. J. Clin. Oncol. 2005, 23, 1875-1884. [CrossRef] [PubMed]

46. Edelman, M.J.; Bauer, K.S., Jr.; Wu, S.; Smith, R.; Bisacia, S.; Dancey, J. Phase I and pharmacokinetic study of 7hydroxystaurosporine and carboplatin in advanced solid tumors. Clin. Cancer Res. 2007, 13, 2667-2674. [CrossRef]

47. Fracasso, P.M.; Williams, K.J.; Chen, R.C.; Picus, J.; Ma, C.X.; Ellis, M.J.; Tan, B.R.; Pluard, T.J.; Adkins, D.R.; Naughton, M.J.; et al. A phase 1 study of UCN-01 in combination with irinotecan in patients with resistant solid tumor malignancies. Cancer Chemother. Pharmacol. 2011, 67, 1225-1237. [CrossRef]

48. Ma, C.X.; Ellis, M.J.; Petroni, G.R.; Guo, Z.; Cai, S.R.; Ryan, C.E.; Craig Lockhart, A.; Naughton, M.J.; Pluard, T.J.; Brenin, C.M.; et al. A phase II study of UCN-01 in combination with irinotecan in patients with metastatic triple negative breast cancer. Breast Cancer Res. Treat. 2013, 137, 483-492. [CrossRef]

49. Hotte, S.J.; Oza, A.; Winquist, E.W.; Moore, M.; Chen, E.X.; Brown, S.; Pond, G.R.; Dancey, J.E.; Hirte, H.W. Phase I trial of UCN-01 in combination with topotecan in patients with advanced solid cancers: A Princess Margaret Hospital Phase II Consortium study. Ann. Oncol. 2006, 17, 334-340. [CrossRef]

50. Welch, S.; Hirte, H.W.; Carey, M.S.; Hotte, S.J.; Tsao, M.S.; Brown, S.; Pond, G.R.; Dancey, J.E.; Oza, A.M. UCN-01 in combination with topotecan in patients with advanced recurrent ovarian cancer: A study of the Princess Margaret Hospital Phase II consortium. Gynecol. Oncol. 2007, 106, 305-310. [CrossRef]

51. Fabbro, D.; Buchdunger, E.; Wood, J.; Mestan, J.; Hofmann, F.; Ferrari, S.; Mett, H.; O’Reilly, T.; Meyer, T. Inhibitors of protein kinases: CGP 41251, a protein kinase inhibitor with potential as an anticancer agent. Pharmacol. Ther. 1999, 82, 293-301. [CrossRef]

52. Fabbro, D.; Ruetz, S.; Bodis, S.; Pruschy, M.; Csermak, K.; Man, A.; Campochiaro, P.; Wood, J.; O’Reilly, T.; Meyer, T. PKC412-a protein kinase inhibitor with a broad therapeutic potential. Anticancer Drug Des. 2000, 15, 17-28. [PubMed]

53. Daver, N.; Schlenk, R.F.; Russell, N.H.; Levis, M.J. Targeting FLT3 mutations in AML: Review of current knowledge and evidence. Leukemia 2019, 33, 299-312. [CrossRef] [PubMed]

54. Grundler, R.; Thiede, C.; Miething, C.; Steudel, C.; Peschel, C.; Duyster, J. Sensitivity toward tyrosine kinase inhibitors varies between different activating mutations of the FLT3 receptor. Blood 2003, 102, 646-651. [CrossRef]

55. Weisberg, E.; Boulton, C.; Kelly, L.M.; Manley, P.; Fabbro, D.; Meyer, T.; Gilliland, D.G.; Griffin, J.D. Inhibition of mutant FLT3 receptors in leukemia cells by the small molecule tyrosine kinase inhibitor PKC412. Cancer Cell 2002, 1, 433-443. [CrossRef]

56. Stone, R.M.; Mandrekar, S.J.; Sanford, B.L.; Laumann, K.; Geyer, S.; Bloomfield, C.D.; Thiede, C.; Prior, T.W.; Döhner, K.; Marcucci, G.; et al. Midostaurin plus chemotherapy for acute myeloid leukemia with a FLT3 mutation. N. Engl. J. Med. 2017, 377, 454-464. [CrossRef] [PubMed]

57. Valent, P.; Akin, C.; Metcalfe, D.D. Mastocytosis: 2016 updated WHO classification and novel emerging treatment concepts. Blood 2016, 129, 1420-1427. [CrossRef]

58. Gotlib, J.; Berubé, C.; Growney, J.D.; Chen, C.C.; George, T.I.; Williams, C.; Kajiguchi, T.; Ruan, J.; Lilleberg, S.L.; Durocher, J.A.; et al. Activity of the tyrosine kinase inhibitor PKC412 in a patient with mast cell leukemia with the D816V KIT mutation. Blood 2005, 106, 2865-2870. [CrossRef]

59. Gleixner, K.V.; Mayerhofer, M.; Aichberger, K.J.; Derdak, S.; Sonneck, K.; Böhm, A.; Gruze, A.; Samorapoompichit, P.; Manley, P.W.; Fabbro, D.; et al. PKC412 inhibits in vitro growth of neoplastic human mast cells expressing the D816V-mutated variant of KIT: Comparison with AMN107, imatinib, and cladribine (2CdA) and evaluation of cooperative drug effects. Blood 2006, 107, 752-759. [CrossRef]

60. Gleixner, K.V.; Mayerhofer, M.; Sonneck, K.; Gruze, A.; Samorapoompichit, P.; Baumgartner, C.; Lee, F.Y.; Aichberger, K.J.; Manley, P.W.; Fabbro, D.; et al. Synergistic growth-inhibitory effects of two tyrosine kinase inhibitors, dasatinib and PKC412, on neoplastic mast cells expressing the D816V-mutated oncogenic variant of KIT. Haematologica 2007, 92, 1451-1459. [CrossRef]

61. DeAngelo, D.J.; George, T.I.; Linder, A.; Langford, C.; Perkins, C.; Ma, J.; Westervelt, P.; Merker, J.D.; Berube, C.; Coutre, S.; et al. Efficacy and safety of midostaurin in patients with advanced systemic mastocytosis: 10-year median follow-up of a phase II trial. Leukemia 2018, 32, 470-478. [CrossRef] [PubMed]

62. Gotlib, J.; Kluin-Nelemans, H.C.; George, T.I.; Akin, C.; Sotlar, K.; Hermine, O.; Awan, F.T.; Hexner, E.; Mauro, M.J.; Sternberg, D.W.; et al. Efficacy and safety of midostaurin in advanced systemic mastocytosis. N. Engl. J. Med. 2016, 374, $2530-2541$. [CrossRef] [PubMed]

63. Tremblay, G.; Dolph, M.; Patel, S.; Brandt, P.; Forsythe, A. Cost-effectiveness analysis for midostaurin versus standard of care in acute myeloid leukemia in the United Kingdom. Cost Eff. Resour. Alloc. 2018, 16, 33. [CrossRef] [PubMed]

64. Schlenk, R.F.; Weber, D.; Fiedler, W.; Salih, H.R.; Wulf, G.; Salwender, H.; Schroeder, T.; Kindler, T.; Lübbert, M.; Wolf, D.; et al. Midostaurin added to chemotherapy and continued single-agent maintenance therapy in acute myeloid leukemia with FLT3-ITD. Blood 2019, 133, 840-851. [CrossRef] [PubMed]

65. ClinicalTrials.gov. U.S. National Library of Medicine. Available online: $\mathrm{https}: / / \mathrm{clinicaltrials} \cdot \mathrm{gov} / \mathrm{ct} 2 / \mathrm{results}$ ?cond=\&term $=$ Midostaurin \&cntry $=\&$ state $=\&$ city $=\&$ dist $=($ accessed on 20 August 2020).

66. Cortes, J.; Perl, A.E.; Döhner, H.; Kantarjian, H.; Martinelli, G.; Kovacsovics, T.; Rousselot, P.; Steffen, B.; Dombret, H.; Estey, E.; et al. Quizartinib, an FLT3 inhibitor, as monotherapy in patients with relapsed or refractory acute myeloid leukaemia: An open-label, multicentre, single-arm, phase 2 trial. Lancet Oncol. 2018, 19, 889-903. [CrossRef] 
67. Perl, A.E.; Martinelli, G.; Cortes, J.E.; Neubauer, A.; Berman, E.; Paolini, S.; Montesinos, P.; Baer, M.R.; Larson, R.A.; Ustun, C.; et al. Gilteritinib or chemotherapy for relapsed or refractory FLT3-mutated AML. N. Engl. J. Med. 2019, 381, 1728-1740. [CrossRef]

68. Toullec, D.; Pianetti, P.; Coste, H.; Bellevergue, P.; Grand-Perret, T.; Ajakane, M.; Baudet, V.; Boissin, P.; Boursier, E.; Loriolle, F.; et al. The bisindolylmaleimide GF 109203X is a potent and selective inhibitor of protein kinase C. J. Biol. Chem. 1991, 266, 15771-15781. [CrossRef]

69. Wilkinson, S.E.; Parker, P.J.; Nixon, J.S. Isoenzyme specificity of bisindolylmaleimides, selective inhibitors of protein kinase C. Biochem. J. 1993, 294, 335-357. [CrossRef] [PubMed]

70. Graff, J.R.; McNulty, A.M.; Hanna, K.R.; Konicek, B.W.; Lynch, R.L.; Bailey, S.N.; Banks, C.; Capen, A.; Goode, R.; Lewis, J.E.; et al. The protein kinase C $\beta$-selective inhibitor, Enzastaurin ( $\mathrm{LY} 317615 . \mathrm{HCl})$, suppresses signaling through the AKT pathway, induces apoptosis, and suppresses growth of human colon cancer and glioblastoma xenografts. Cancer Res. 2005, 65, 7462-7469. [CrossRef]

71. Jirousek, M.R.; Gillig, J.R.; Gonzalez, C.M.; Heath, W.F.; McDonald, J.H., 3rd; Neel, D.A.; Rito, C.J.; Singh, U.; Stramm, L.E.; Melikian-Badalian, A.; et al. (S)-13-[(dimethylamino)methyl]-10,11,14,15-tetrahydro-4,9:16, 21-dimetheno-1H, 13Hdibenzo[e,k]pyrrolo[3,4-h][1,4,13] oxadiazacyclohexadecene-1,3(2H)-d ione (LY333531) and related analogues: Isozyme selective inhibitors of protein kinase C $\beta$. J. Med Chem. 1996, 39, 2664-2671. [CrossRef]

72. Davies, S.P.; Reddy, H.; Caivano, M.; Cohen, P. Specificity and mechanism of action of some commonly used protein kinase inhibitors. Biochem. J. 2000, 351, 95-105. [CrossRef]

73. Komander, D.; Kular, G.S.; Schüttelkopf, A.W.; Deak, M.; Prakash, K.R.; Bain, J.; Elliott, M.; Garrido-Franco, M.; Kozikowski, A.P.; Alessi, D.R.; et al. Interactions of LY333531 and other bisindolyl maleimide inhibitors with PDK1. Structure 2004, 12, 215-226. [CrossRef]

74. Rizvi, M.A.; Ghias, K.; Davies, K.M.; Ma, C.; Weinberg, F.; Munshi, H.G.; Krett, N.L.; Rosen, S.T. Enzastaurin (LY317615), a protein kinase $C \beta$ inhibitor, inhibits the AKT pathway and induces apoptosis in multiple myeloma cell lines. Mol. Cancer Ther. 2006, 5, 1783-1789. [CrossRef]

75. Neri, A.; Marmiroli, S.; Tassone, P.; Lombardi, L.; Nobili, L.; Verdelli, D.; Civallero, M.; Cosenza, M.; Bertacchini, J.; Federico, M.; et al. The oral protein-kinase C $\beta$ inhibitor enzastaurin (LY317615) suppresses signalling through the AKT pathway, inhibits proliferation and induces apoptosis in multiple myeloma cell lines. Leuk. Lymphoma 2008, 49, 1374-1383. [CrossRef]

76. Lee, S.H.; Chen, T.; Zhou, J.; Hofmann, J.; Bepler, G. Protein kinase C- $\beta$ gene variants, pathway activation, and enzastaurin activity in lung cancer. Clin. Lung Cancer 2010, 11, 169-175. [CrossRef]

77. Fields, A.P.; Calcagno, S.R.; Krishna, M.; Rak, S.; Leitges, M.; Murray, N.R. Protein kinase C $\beta$ is an effective target for chemoprevention of colon cancer. Cancer Res. 2009, 69, 1643-1650. [CrossRef]

78. Odia, Y.; Iwamoto, F.M.; Moustakas, A.; Fraum, T.J.; Salgado, C.A.; Li, A.; Kreisl, T.N.; Sul, J.; Butman, J.A.; Fine, H.A. A phase II trial of enzastaurin (LY317615) in combination with bevacizumab in adults with recurrent malignant gliomas. J. Neurooncol. 2016, 127, 127-135. [CrossRef]

79. Wick, W.; Puduvalli, V.K.; Chamberlain, M.C.; van den Bent, M.J.; Carpentier, A.F.; Cher, L.M.; Mason, W.; Weller, M.; Hong, S.; Musib, L.; et al. Phase III study of enzastaurin compared with lomustine in the treatment of recurrent intracranial glioblastoma. $J$. Clin. Oncol. 2010, 28, 1168-1174. [CrossRef]

80. Crump, M.; Leppä, S.; Fayad, L.; Lee, J.J.; Di Rocco, A.; Ogura, M.; Hagberg, H.; Schnell, F.; Rifkin, R.; Mackensen, A.; et al. Randomized, double-blind, phase III trial of enzastaurin versus placebo in patients achieving remission after first-line therapy for high-risk diffuse large B-cell lymphoma. J. Clin. Oncol. 2016, 34, 2484-2492. [CrossRef]

81. Jourdan, E.; Leblond, V.; Maisonneuve, H.; Benhadji, K.A.; Hossain, A.M.; Nguyen, T.S.; Wooldridge, J.E.; Moreau, P. A multicenter phase II study of single-agent enzastaurin in previously treated multiple myeloma. Leuk. Lymphoma 2014, 55, 2013-2017. [CrossRef] [PubMed]

82. Grønberg, B.H.; Ciuleanu, T.; Fløtten, Ø.; Knuuttila, A.; Abel, E.; Langer, S.W.; Krejcy, K.; Liepa, A.M.; Munoz, M.; HahkaKemppinen, M.; et al. A placebo-controlled, randomized phase II study of maintenance enzastaurin following whole brain radiation therapy in the treatment of brain metastases from lung cancer. Lung Cancer 2012, 78, 63-69. [CrossRef]

83. Usha, L.; Sill, M.W.; Darcy, K.M.; Benbrook, D.M.; Hurteau, J.A.; Michelin, D.P.; Mannel, R.S.; Hanjani, P.; De Geest, K.; Godwin, A.K. A Gynecologic Oncology Group phase II trial of the protein kinase C- $\beta$ inhibitor, enzastaurin and evaluation of markers with potential predictive and prognostic value in persistent or recurrent epithelial ovarian and primary peritoneal malignancies. Gynecol. Oncol. 2011, 121, 455-461. [CrossRef]

84. Morschhauser, F.; Seymour, J.F.; Kluin-Nelemans, H.C.; Grigg, A.; Wolf, M.; Pfreundschuh, M.; Tilly, H.; Raemaekers, J.; van't Veer, M.B.; Milpied, N.; et al. A phase II study of enzastaurin, a protein kinase C $\beta$ inhibitor, in patients with relapsed or refractory mantle cell lymphoma. Ann. Oncol. 2008, 19, 247-253. [CrossRef] [PubMed]

85. Mina, L.; Krop, I.; Zon, R.T.; Isakoff, S.J.; Schneider, C.J.; Yu, M.; Johnson, C.; Vaughn, L.G.; Wang, Y.; Hristova-Kazmierski, M.; et al. A phase II study of oral enzastaurin in patients with metastatic breast cancer previously treated with an anthracycline and a taxane containing regimen. Investig. New Drugs 2009, 27, 565-570. [CrossRef] [PubMed]

86. Querfeld, C.; Kuzel, T.M.; Kim, Y.H.; Porcu, P.; Duvic, M.; Musiek, A.; Rook, A.H.; Mark, L.A.; Pinter-Brown, L.; Hamid, O.; et al. Multicenter phase II trial of enzastaurin in patients with relapsed or refractory advanced cutaneous T-cell lymphoma. Leuk. Lymphoma 2011, 52, 1474-1480. [CrossRef] 
87. Clément-Duchêne, C.; Natale, R.B.; Jahan, T.; Krupitskaya, Y.; Osarogiagbon, R.; Sanborn, R.E.; Bernstein, E.D.; Dudek, A.Z.; Latz, J.E.; Shi, P.; et al. A phase II study of enzastaurin in combination with erlotinib in patients with previously treated advanced non-small cell lung cancer. Lung Cancer 2012, 78, 57-62. [CrossRef]

88. Butowski, N.; Chang, S.M.; Lamborn, K.R.; Polley, M.Y.; Pieper, R.; Costello, J.F.; Vandenberg, S.; Parvataneni, R.; Nicole, A.; Sneed, P.K.; et al. Phase II and pharmacogenomics study of enzastaurin plus temozolomide during and following radiation therapy in patients with newly diagnosed glioblastoma multiforme and gliosarcoma. Neuro-Oncology 2011, 13, 1331-1338. [CrossRef]

89. Dreicer, R.; Garcia, J.; Rini, B.; Vogelzang, N.; Srinivas, S.; Somer, B.; Shi, P.; Kania, M.; Raghavan, D. A randomized, double-blind, placebo-controlled, Phase II study with and without enzastaurin in combination with docetaxel-based chemotherapy in patients with castration-resistant metastatic prostate cancer. Investig. New Drugs. 2013, 31, 1044-1050. [CrossRef]

90. Vergote, I.B.; Chekerov, R.; Amant, F.; Harter, P.; Casado, A.; Emerich, J.; Bauknecht, T.; Mansouri, K.; Myrand, S.P.; Nguyen, T.S.; et al. Randomized, phase II, placebo-controlled, double-blind study with and without enzastaurin in combination with paclitaxel and carboplatin as first-line treatment followed by maintenance treatment in advanced ovarian cancer. J. Clin. Oncol. 2013, 31, 3127-3132. [CrossRef] [PubMed]

91. Wolff, R.A.; Fuchs, M.; Di Bartolomeo, M.; Hossain, A.M.; Stoffregen, C.; Nicol, S.; Heinemann, V. A double-blind, randomized, placebo-controlled, phase 2 study of maintenance enzastaurin with 5-fluorouracil/leucovorin plus bevacizumab after first-line therapy for metastatic colorectal cancer. Cancer 2012, 118, 4132-4138. [CrossRef] [PubMed]

92. Chiappori, A.; Bepler, G.; Barlesi, F.; Soria, J.C.; Reck, M.; Bearz, A.; Barata, F.; Scagliotti, G.; Park, K.; Wagle, A.; et al. Phase II, double-blinded, randomized study of enzastaurin plus pemetrexed as second-line therapy in patients with advanced non-small cell lung cancer. J. Thorac. Oncol. 2010, 5, 369-375. [CrossRef] [PubMed]

93. Richards, D.A.; Kuefler, P.R.; Becerra, C.; Wilfong, L.S.; Gersh, R.H.; Boehm, K.A.; Zhan, F.; Asmar, L.; Myrand, S.P.; Hozak, R.R.; et al. Gemcitabine plus enzastaurin or single-agent gemcitabine in locally advanced or metastatic pancreatic cancer: Results of a phase II, randomized, noncomparative study. Investig. New Drugs 2011, 29, 144-153. [CrossRef]

94. Kilburn, L.B.; Kocak, M.; Decker, R.L.; Wetmore, C.; Chintagumpala, M.; Su, J.; Goldman, S.; Banerjee, A.; Gilbertson, R.; Fouladi, M.; et al. A phase 1 and pharmacokinetic study of enzastaurin in pediatric patients with refractory primary central nervous system tumors: A pediatric brain tumor consortium study. Neuro-Oncology 2015, 17, 303-311. [CrossRef]

95. Nonaka, A.; Kiryu, J.; Tsujikawa, A.; Yamashiro, K.; Miyamoto, K.; Nishiwaki, H.; Honda, Y.; Ogura, Y. PKC- $\beta$ inhibitor (LY333531) attenuates leukocyte entrapment in retinal microcirculation of diabetic rats. Investig. Ophthalmol. Vis. Sci. 2000, 41, 2702-2706.

96. Abiko, T.; Abiko, A.; Clermont, A.C.; Shoelson, B.; Horio, N.; Takahashi, J.; Adamis, A.P.; King, G.L.; Bursell, S.E. Characterization of retinal leukostasis and hemodynamics in insulin resistance and diabetes: Role of oxidants and protein kinase-C activation. Diabetes 2003, 52, 829-837. [CrossRef] [PubMed]

97. Yokota, T.; Ma, R.C.; Park, J.Y.; Isshiki, K.; Sotiropoulos, K.B.; Rauniyar, R.K.; Bornfeldt, K.E.; King, G.L. Role of protein kinase C on the expression of platelet-derived growth factor and endothelin-1 in the retina of diabetic rats and cultured retinal capillary pericytes. Diabetes 2003, 52, 838-845. [CrossRef] [PubMed]

98. Nakamura, S.; Chikaraishi, Y.; Tsuruma, K.; Shimazawa, M.; Hara, H. Ruboxistaurin, a PKC $\beta$ inhibitor, inhibits retinal neovascularization via suppression of phosphorylation of ERK1/2 and Akt. Exp. Eye Res. 2010, 90, 137-145. [CrossRef] [PubMed]

99. Said, G. Diabetic neuropathy-a review. Nat. Clin. Pract. Neurol. 2007, 3, 331-340. [CrossRef]

100. Feldman, E.L.; Callaghan, B.C.; Pop-Busui, R.; Zochodne, D.W.; Wright, D.E.; Bennett, D.L.; Bril, V.; Russell, J.W.; Viswanathan, V. Diabetic neuropathy. Nat. Rev. Dis. Primers 2019, 5, 41. [CrossRef]

101. Kim, H.; Sasaki, T.; Maeda, K.; Koya, D.; Kashiwagi, A.; Yasuda, H. Protein kinase C $\beta$ selective inhibitor LY333531 attenuates diabetic hyperalgesia through ameliorating cGMP level of dorsal root ganglion neurons. Diabetes 2003, 52, 2102-2109. [CrossRef]

102. Kitada, M.; Koya, D.; Sugimoto, T.; Isono, M.; Araki, S.; Kashiwagi, A.; Haneda, M. Translocation of glomerular p47phox and p67phox by protein kinase C- $\beta$ activation is required for oxidative stress in diabetic nephropathy. Diabetes 2003, 52, 2603-2614. [CrossRef] [PubMed]

103. Kato, M.; Yuan, H.; Xu, Z.G.; Lanting, L.; Li, S.L.; Wang, M.; Hu, M.C.; Reddy, M.A.; Natarajan, R. Role of the Akt/FoxO3a pathway in TGF- $\beta 1$-mediated mesangial cell dysfunction: A novel mechanism related to diabetic kidney disease. J. Am. Soc. Nephrol. 2006, 17, 3325-3335. [CrossRef] [PubMed]

104. Wu, D.; Peng, F.; Zhang, B.; Ingram, A.J.; Kelly, D.J.; Gilbert, R.E.; Gao, B.; Krepinsky, J.C. PKC- $\beta 1$ mediates glucose-induced Akt activation and TGF-beta1 upregulation in mesangial cells. J. Am. Soc. Nephrol. 2009, 20, 554-566. [CrossRef] [PubMed]

105. Kelly, D.J.; Chanty, A.; Gow, R.M.; Zhang, Y.; Gilbert, R.E. Protein kinase C $\beta$ inhibition attenuates osteopontin expression, macrophage recruitment, and tubulointerstitial injury in advanced experimental diabetic nephropathy. J. Am. Soc. Nephrol. 2005, 16, 1654-1660. [CrossRef] [PubMed]

106. Sheetz, M.J.; Aiello, L.P.; Shahri, N.; Davis, M.D.; Kles, K.A.; Danis, R.P.; Mbdv Study Group. Effect of ruboxistaurin (RBX) On visual acuity decline over a 6-year period with cessation and reinstitution of therapy: Results of an open-label extension of the Protein Kinase C Diabetic Retinopathy Study 2 (PKC-DRS2). Retina 2011, 31, 1053-1059. [CrossRef]

107. Sheetz, M.J.; Aiello, L.P.; Davis, M.D.; Danis, R.; Bek, T.; Cunha-Vaz, J.; Shahri, N.; Berg, P.H.; MBDL and MBCU Study Groups. The effect of the oral PKC $\beta$ inhibitor ruboxistaurin on vision loss in two phase 3 studies. Investig. Ophthalmol. Vis. Sci. 2013, 54, 1750-1757. [CrossRef] 
108. Tesfaye, S.; Tandan, R.; Bastyr, E.J., 3rd; Kles, K.A.; Skljarevski, V.; Price, K.L.; Ruboxistaurin Study Group. Factors that impact symptomatic diabetic peripheral neuropathy in placebo-administered patients from two 1-year clinical trials. Diabetes Care 2007, 30, 2626-2632. [CrossRef]

109. Skvara, H.; Dawid, M.; Kleyn, E.; Wolff, B.; Meingassner, J.G.; Knight, H.; Dumortier, T.; Kopp, T.; Fallahi, N.; Stary, G.; et al. The PKC inhibitor AEB071 may be a therapeutic option for psoriasis. J. Clin. Investig. 2008, 118, 3151-3159. [CrossRef]

110. Wagner, J.; von Matt, P.; Sedrani, R.; Albert, R.; Cooke, N.; Ehrhardt, C.; Geiser, M.; Rummel, G.; Stark, W.; Strauss, A.; et al. Discovery of 3-(1H-indol-3-yl)-4-[2-(4-methylpiperazin-1-yl)quinazolin-4-yl]pyrrole-2,5-dione (AEB071), a potent and selective inhibitor of protein kinase C isotypes. J. Med. Chem. 2009, 52, 6193-6196. [CrossRef]

111. Evenou, J.P.; Wagner, J.; Zenke, G.; Brinkmann, V.; Wagner, K.; Kovarik, J.; Welzenbach, K.A.; Weitz-Schmidt, G.; Guntermann, C.; Towbin, H.; et al. The potent protein kinase C-selective inhibitor AEB071 (sotrastaurin) represents a new class of immunosuppressive agents affecting early T-cell activation. J. Pharmacol. Exp. Ther. 2009, 330, 792-801. [CrossRef]

112. Martina, M.N.; Ramirez Bajo, M.J.; Bañon-Maneus, E.; Moya Rull, D.; Hierro-Garcia, N.; Revuelta, I.; Campistol, J.M.; Rovira, J.; Diekmann, F. Inhibition of JAK3 and PKC via immunosuppressive drugs tofacitinib and sotrastaurin inhibits proliferation of human B lymphocytes in vitro. Transpl. Proc. 2016, 48, 3046-3052. [CrossRef] [PubMed]

113. Wong, T.C.; Lo, C.M.; Fung, J.Y. Emerging drugs for prevention of T-cell mediated rejection in liver and kidney transplantation. Expert. Opin. Emerg. Drugs 2017, 22, 123-136. [CrossRef]

114. Friman, S.; Arns, W.; Nashan, B.; Vincenti, F.; Banas, B.; Budde, K.; Cibrik, D.; Chan, L.; Klempnauer, J.; Mulgaonkar, S.; et al. Sotrastaurin. a novel small molecule inhibiting protein-kinase C: Randomized phase II study in renal transplant recipients. Am. J. Transpl. 2011, 11, 1444-1455. [CrossRef] [PubMed]

115. Pascher, A.; De Simone, P.; Pratschke, J.; Salamé, E.; Pirenne, J.; Isoneimi, H.; Bijarnia, M.; Krishnan, I.; Klupp, J. Protein Kinase C Inhibitor sotrastaurin in de novo liver transplant recipients: A randomized phase II trial. Am. J. Transpl. 2015, 15, 1283-1292. [CrossRef]

116. Russ, G.R.; Tedesco-Silva, H.; Kuypers, D.R.; Cohney, S.; Langer, R.M.; Witzke, O.; Eris, J.; Sommerer, C.; von Zur-Mühlen, B.; Woodle, E.S.; et al. Efficacy of sotrastaurin plus tacrolimus after de novo kidney transplantation: Randomized, phase II trial results. Am. J. Transpl. 2013, 13, 1746-1756. [CrossRef] [PubMed]

117. Tedesco-Silva, H.; Kho, M.M.; Hartmann, A.; Vitko, S.; Russ, G.; Rostaing, L.; Budde, K.; Campistol, J.M.; Eris, J.; Krishnan, I.; et al. Sotrastaurin in calcineurin inhibitor-free regimen using everolimus in de novo kidney transplant recipients. Am. J. Transpl. 2013, 13, 1757-1768. [CrossRef] [PubMed]

118. Naylor, T.L.; Tang, H.; Ratsch, B.A.; Enns, A.; Loo, A.; Chen, L.; Lenz, P.; Waters, N.J.; Schuler, W.; Dörken, B.; et al. Protein kinase $\mathrm{C}$ inhibitor sotrastaurin selectively inhibits the growth of CD79 mutant diffuse large B-cell lymphomas. Cancer Res. 2011, 71, 2643-2653. [CrossRef]

119. Chang, G.; Zheng, J.; Xiao, W.; Chang, S.; Wei, Q.; Wu, H.; Tao, Y.; Yang, G.; Xie, B.; Lan, X.; et al. PKC inhibition of sotrastaurin has antitumor activity in diffuse large B-cell lymphoma via regulating the expression of MCT-1. Acta Biochim. Biophys. Sin. 2018, 50, 399-407. [CrossRef]

120. Piperno-Neumann, S.; Larkin, J.; Carvajal, R.D.; Luke, J.J.; Schwartz, G.K.; Hodi, F.S.; Sablin, M.P.; Shoushtari, A.N.; Szpakowski, S.; Chowdhury, N.R.; et al. Genomic profiling of metastatic uveal melanoma and clinical results of a phase I study of the protein kinase C inhibitor AEB071. Mol. Cancer Ther. 2020, 19, 1031-1039. [CrossRef]

121. Kulanthaivel, P.; Hallock, Y.F.; Boros, C.; Hamiton, S.M.; Janzen, W.P.; Ballas, L.M.; Loomis, C.R.; Jiang, J.B.; Katz, B.; Stainer, J.R.; et al. Balanol: A novel and potent inhibitor of protein kinase C from the fungus Verticillium balanoides. J. Am. Chem. Soc. 1993, 14, 6452-6453. [CrossRef]

122. Lai, Y.S.; Mendoza, J.S.; Hubbard, F.; Kalter, K. Synthesis and PKC inhibitory activities of balanol analogs with a cyclopentane substructure. Bioorg. Med. Chem. Lett. 1995, 5, 2155-2160. [CrossRef]

123. Defauw, J.M.; Murphy, M.M.; Jagdmann, G.E., Jr.; Hu, H.; Lampe, J.W.; Hollinshead, S.P.; Mitchell, T.J.; Crane, H.M.; Heerding, J.M.; Mendoza, J.S.; et al. Synthesis and protein kinase C inhibitory activities of acyclic balanol analogs that are highly selective for protein kinase C over protein kinase A. J. Med. Chem. 1996, 39, 5215-5227. [CrossRef] [PubMed]

124. Patel, A.R.; Hardianto, A.; Ranganathan, S.; Liu, F. Divergent response of homologous ATP sites to stereospecific ligand fluorination for selectivity enhancement. Org. Biomol. Chem. 2017, 15, 1570-1574. [CrossRef] [PubMed]

125. O'Brian, C.A.; Ward, N.E. ATP-sensitive binding of melittin to the catalytic domain of protein kinase C. Mol. Pharmacol. 1989, 36, 355-359. [PubMed]

126. Katoh, N. Inhibition by melittin of phosphorylation by protein kinase C of annexin I from cow mammary gland. J. Vet. Med. Sci. 2002, 64, 779-783. [CrossRef]

127. Gravitt, K.R.; Ward, N.E.; O’Brian, C.A. Inhibition of protein kinase C by melittin: Antagonism of binding interactions between melittin and the catalytic domain by active-site binding of MgATP. Biochem. Pharmacol. 1994, 47, 425-427. [CrossRef]

128. Eichholtz, T.; de Bont, D.B.; de Widt, J.; Liskamp, R.M.; Ploegh, H.L. A myristoylated pseudosubstrate peptide, a novel protein kinase C inhibitor. J. Biol. Chem. 1993, 268, 1982-1986. [CrossRef]

129. Ward, N.E.; O'Brian, C.A. Inhibition of protein kinase C by N-myristoylated peptide substrate analogs. Biochemistry 1993, 32, 11903-11909. [CrossRef]

130. Hofmann, J. The potential for isoenzyme-selective modulation of protein kinase C. FASEB J. 1997, 11, 649-669. [CrossRef] 
131. Zaliani, A.; Pinori, M.; Ball, H.L.; DiGregorio, G.; Cremonesi, P.; Mascagni, P. The interaction of myristylated peptides with the catalytic domain of protein kinase $\mathrm{C}$ revealed by their sequence palindromy and the identification of a myristyl binding site. Protein Eng. 1998, 11, 803-810. [CrossRef]

132. Eller, M.; Järv, J.; Toomik, R.; Ragnarsson, U.; Ekman, P.; Engström, L. Substrate specificity of protein kinase C studied with peptides containing D-amino acid residues. J. Biol. Chem. 1993, 114, 177-180. [CrossRef]

133. House, C.; Kemp, B.E. Protein kinase C contains a pseudosubstrate prototope in its regulatory domain. Science 1987, 238, 1726-1728. [CrossRef]

134. Baxter, G.; Oto, E.; Daniel-Issakani, S.; Strulovici, B. Constitutive presence of a catalytic fragment of protein kinase C $\varepsilon$ in a small cell lung carcinoma cell line. J. Biol. Chem. 1992, 267, 1910-1917. [CrossRef]

135. Bogard, A.S.; Tavalin, S.J. Protein kinase C (PKC) $\zeta$ pseudosubstrate inhibitor peptide promiscuously binds PKC family isoforms and disrupts conventional PKC targeting and translocation. Mol. Pharmacol. 2015, 88, 728-735. [CrossRef] [PubMed]

136. Johnson, J.A.; Gray, M.O.; Chen, C.H.; Mochly-Rosen, D. A protein kinase C translocation inhibitor as an isozyme-selective antagonist of cardiac function. J. Biol. Chem. 1996, 271, 24962-24966. [CrossRef] [PubMed]

137. Kim, J.; Thorne, S.H.; Sun, L.; Huang, B.; Mochly-Rosen, D. Sustained inhibition of PKC $\alpha$ reduces intravasation and lung seeding during mammary tumor metastasis in an in vivo mouse model. Oncogene 2011, 30, 323-333. [CrossRef]

138. Stebbins, E.G.; Mochly-Rosen, D. Binding specificity for RACK1 resides in the V5 region of $\beta$ II protein kinase C. J. Biol. Chem. 2001, 276, 29644-29650. [CrossRef]

139. Chen, L.; Hahn, H.; Wu, G.; Chen, C.H.; Liron, T.; Schechtman, D.; Cavallaro, G.; Banci, L.; Guo, Y.; Bolli, R.; et al. Opposing cardioprotective actions and parallel hypertrophic effects of $\delta$ PKC and $\in$ PKC. Proc. Natl. Acad. Sci. USA 2001, 98, 11114-11119. [CrossRef]

140. Lincoff, A.M.; Roe, M.; Aylward, P.; Galla, J.; Rynkiewicz, A.; Guetta, V.; Zelizko, M.; Kleiman, N.; White, H.; McErlean, E.; et al. Inhibition of delta-protein kinase $\mathrm{C}$ by delcasertib as an adjunct to primary percutaneous coronary intervention for acute anterior ST-segment elevation myocardial infarction: Results of the PROTECTION AMI Randomized Controlled. Trial. Eur. Heart J. 2014, 35, 2516-2523. [CrossRef]

141. Cousins, M.J.; Pickthorn, K.; Huang, S.; Critchley, L.; Bell, G. The safety and efficacy of KAI-1678- an inhibitor of epsilon protein kinase $\mathrm{C}(\varepsilon \mathrm{PKC})$-versus lidocaine and placebo for the treatment of postherpetic neuralgia: A crossover study design. Pain Med. 2013, 14, 533-540. [CrossRef]

142. Tarrant, M.K.; Cole, P.A. The chemical biology of protein phosphorylation. Annu. Rev. Biochem. 2009, 78, 797-825. [CrossRef]

143. Herbert, J.M.; Augereau, J.M.; Gleye, J.; Maffrand, J.P. Chelerythrine is a potent and specific inhibitor of protein kinase C. Biochem. Biophys. Res. Commun. 1990, 172, 993-999. [CrossRef]

144. Chmura, S.J.; Dolan, M.E.; Cha, A.; Mauceri, H.J.; Kufe, D.W.; Weichselbaum, R.R. In vitro and in vivo activity of protein kinase C inhibitor chelerythrine chloride induces tumor cell toxicity and growth delay in vivo. Clin. Cancer Res. 2000, 6, 737-742.

145. Fan, L.; Fan, Y.; Liu, L.; Tao, W.; Shan, X.; Dong, Y. Chelerythrine attenuates the inflammation of lipopolysaccharide-induced acute lung inflammation through NF-kB signaling pathway mediated by Nrf2. Front. Pharmacol. 2018, 9, 1047. [CrossRef]

146. Blázquez, A.B.; Vázquez-Calvo, Á.; Martín-Acebes, M.A.; Saiz, J.C. Pharmacological inhibition of protein kinase C reduces West Nile virus replication. Viruses 2018, 10, E91. [CrossRef]

147. Gong, Y.; Li, S.; Wang, W.; Li, Y.; Ma, W.; Sun, S. In vitro and in vivo activity of chelerythrine against Candida albicans and underlying mechanisms. Future Microbiol. 2019, 14, 1545-1557. [CrossRef] [PubMed]

148. He, N.; Wang, P.; Wang, P.; Ma, C.; Kang, W. Antibacterial mechanism of chelerythrine isolated from root of Toddalia asiatica (Linn) Lam. BMC Complement. Altern. Med. 2018, 18, 261. [CrossRef] [PubMed]

149. Lin, W.; Huang, J.; Yuan, Z.; Feng, S.; Xie, Y.; Ma, W. Protein kinase C inhibitor chelerythrine selectively inhibits proliferation of triple-negative breast cancer cells. Sci. Rep. 2017, 7, 2022. [CrossRef]

150. Slaninová, I.; Táborská, E.; Bochoráková, H.; Slanina, J. Interaction of benzo[c]phenanthridine and protoberberine alkaloids with animal and yeast cells. Cell Biol. Toxicol. 2001, 17, 51-63. [CrossRef] [PubMed]

151. He, M.; Yang, Z.; Zhang, L.; Song, C.; Li, Y.; Zhang, X. Additive effects of cherlerythrine chloride combination with erlotinib in human non-small cell lung cancer cells. PLoS ONE 2017, 12, e0175466. [CrossRef]

152. Lee, S.K.; Qing, W.G.; Mar, W.; Luyengi, L.; Mehta, R.G.; Kawanishi, K.; Fong, H.H.; Beecher, C.W.; Kinghorn, A.D.; Pezzuto, J.M. Angoline and chelerythrine, benzophenanthridine alkaloids that do not inhibit protein kinase C. J. Biol. Chem. 1998, 273, 19829-19833. [CrossRef]

153. Noh, K.M.; Hwang, J.Y.; Shin, H.C.; Koh, J.Y. A novel neuroprotective mechanism of riluzole: Direct inhibition of protein kinase C. Neurobiol. Dis. 2000, 7, 375-383. [CrossRef]

154. Lamanauskas, N.; Nistri, A. Riluzole blocks persistent $\mathrm{Na}^{+}$and $\mathrm{Ca}^{2+}$ currents and modulates release of glutamate via presynaptic NMDA receptors on neonatal rat hypoglossal motoneurons in vitro. Eur. J. Neurosci. 2008, 27, 2501-2514. [CrossRef] [PubMed]

155. Yoo, M.H.; Hyun, H.J.; Kob, J.Y.; Yoon, Y.H. Riluzole inhibits VEGF-induced endothelial cell proliferation in vitro and hyperoxiainduced abnormal vessel formation in vivo. Investig. Ophthalmol. Vis. Sci. 2005, 46, 4780-4787. [CrossRef] [PubMed]

156. Ekokoski, E.; Aitio, O.; Törnquist, K.; Yli-Kauhaluoma, J.; Tuominen, R.K. HIV-1 Tat-peptide inhibits protein kinase C and protein kinase A through substrate competition. Eur. J. Pharm. Sci. 2010, 40, 404-411. [CrossRef] 
157. Sajan, M.P.; Nimal, S.; Mastorides, S.; Acevedo-Duncan, M.; Kahn, C.R.; Fields, A.P.; Braun, U.; Leitges, M.; Farese, R.V. Correction of metabolic abnormalities in a rodent model of obesity, metabolic syndrome, and type 2 diabetes mellitus by inhibitors of hepatic protein kinase C-ı. Metabolism 2012, 61, 459-469. [CrossRef] [PubMed]

158. Smith, I.M.; Hoshi, N. ATP competitive protein kinase C inhibitors demonstrate distinct state-dependent inhibition. PLoS ONE 2011, 6, e26338. [CrossRef]

159. Lee, A.M.; Kanter, B.R.; Wang, D.; Lim, J.P.; Zou, M.E.; Qiu, C.; McMahon, T.; Dadgar, J.; Fischbach-Weiss, S.C.; Messing, R.O. Prkcz null mice show normal learning and memory. Nature 2013, 493, 416-419. [CrossRef] [PubMed]

160. Wu-Zhang, A.X.; Schramm, C.L.; Nabavi, S.; Malinow, R.; Newton, A.C. Cellular pharmacology of protein kinase M $\zeta$ (PKM $\zeta$ ) contrasts with its in vitro profile: Implications for PKM $\zeta$ as a mediator of memory. J. Biol. Chem. 2012, 287, 2879-12885. [CrossRef] [PubMed]

161. Tsai, L.C.; Xie, L.; Dore, K.; Xie, L.; Del Rio, J.C.; King, C.C.; Martinez-Ariza, G.; Hulme, C.; Malinow, R.; Bourne, P.E.; et al. Zeta inhibitory peptide disrupts electrostatic interactions that maintain atypical protein kinase $\mathrm{C}$ in its active conformation on the scaffold p62. J. Biol. Chem. 2015, 290, 21845-21856. [CrossRef] [PubMed]

162. Ling, D.S.; Benardo, L.S.; Serrano, P.A.; Blace, N.; Kelly, M.T.; Crary, J.F.; Sacktor, T.C. Protein kinase M $\zeta$ is necessary and sufficient for LTP maintenance. Nat. Neurosci. 2002, 5, 295-296. [CrossRef] [PubMed]

163. Volk, L.J.; Bachman, J.L.; Johnson, R.; Yu, Y.; Huganir, R.L. PKM- $\zeta$ is not required for hippocampal synaptic plasticity, learning and memory. Nature 2013, 493, 420-423. [CrossRef] [PubMed]

164. Tsokas, P.; Hsieh, C.; Yao, Y.; Lesburguères, E.; Wallace, E.J.C.; Tcherepanov, A.; Jothianandan, D.; Hartley, B.R.; Pan, L.; Rivard, B.; et al. Compensation for $\mathrm{PKM} \zeta$ in long-term potentiation and spatial long-term memory in mutant mice. Elife 2016, 5, e14846. [CrossRef] [PubMed]

165. Yao, Y.; Shao, C.; Jothianandan, D.; Tcherepanov, A.; Shouval, H.; Sacktor, T.C. Matching biochemical and functional efficacies confirm ZIP as a potent competitive inhibitor of PKM $\zeta$ in neurons. Neuropharmacology 2013, 64, 37-44. [CrossRef] [PubMed]

166. Sadeh, N.; Verbitsky, S.; Dudai, Y.; Segal, M. Zeta inhibitory peptide, a candidate inhibitor of protein kinase $M \zeta$, is excitotoxic to cultured hippocampal neurons. J. Neurosci. 2015, 35, 12404-12411. [CrossRef] [PubMed]

167. Tang, Y.; Chen, A.; Chen, Y.; Guo, L.; Dai, H.; Huang, Y.; Chen, Q.; Lin, C. Zeta inhibitory peptide as a novel therapy to control chronic visceral hypersensitivity in a rat model. PLOS ONE 2016, 11, e0163324. [CrossRef]

168. Yao, J.; Zhang, L.; Lei, W.; Huang, Y.; Zhang, H.; Lu, B.; Yao, Y.; Zhao, L.; Sun, J. Intra-amygdala infusion of zeta inhibitory peptide attenuates neuropathic pain but not inflammatory pain in adult rats. Ann. Palliat. Med. 2019, 8, 660-666. [CrossRef] [PubMed]

169. Gao, X.; Zheng, R.; Ma, X.; Gong, Z.; Xia, D.; Zhou, Q. Elevated level of PKM $\zeta$ underlies the excessive anxiety in an autism model. Front. Mol. Neurosci. 2019, 12, 291. [CrossRef]

170. Opendak, M.; Zanca, R.M.; Anane, E.; Serrano, P.A.; Sullivan, R.M. Developmental transitions in amygdala PKC isoforms and AMPA receptor expression associated with threat memory in infant rats. Sci. Rep. 2018, 8, 14679. [CrossRef] [PubMed]

171. Zhang, Y.; Ouyang, Z.; Lipina, T.V.; Wang, H.; Zhou, Q. Conditioned stimulus presentations alter anxiety level in fear-conditioned mice. Mol. Brain 2019, 12, 28. [CrossRef]

172. Brückle, W.; Dexel, T.; Grasedyck, K.; Schattenkirchner, M. Treatment of psoriatic arthritis with auranofin and gold sodium thiomalate. Clin. Rheumatol. 1994, 13, 209-216. [CrossRef] [PubMed]

173. Jessop, J.D.; O'Sullivan, M.M.; Lewis, P.A.; Williams, L.A.; Camilleri, J.P.; Plant, M.J.; Coles, E.C. A long-term five-year randomized controlled trial of hydroxychloroquine, sodium aurothiomalate, auranofin and penicillamine in the treatment of patients with rheumatoid arthritis. Br. J. Rheumatol. 1998, 37, 992-1002. [CrossRef] [PubMed]

174. Erdogan, E.; Lamark, T.; Stallings-Mann, M.; Lee, J.; Pellecchia, M.; Thompson, E.A.; Johansen, T.; Fields, A.P. Aurothiomalate inhibits transformed growth by targeting the PB1 domain of protein kinase Cı. J. Biol. Chem. 2006, 281, 28450-28459. [CrossRef]

175. Butler, A.M.; Scotti Buzhardt, M.L.; Erdogan, E.; Li, S.; Inman, K.S.; Fields, A.P.; Murray, N.R. A small molecule inhibitor of atypical protein kinase C signaling inhibits pancreatic cancer cell transformed growth and invasion. Oncotarget 2015, 6, 15297-15310. [CrossRef] [PubMed]

176. Stallings-Mann, M.; Jamieson, L.; Regala, R.P.; Weems, C.; Murray, N.R.; Fields, A.P. A novel small-molecule inhibitor of protein kinase Cı blocks transformed growth of non-small-cell lung cancer cells. Cancer Res. 2006, 66, 1767-1774. [CrossRef] [PubMed]

177. Li, H.; Hu., J.; Wu, S.; Wang, L.; Cao, X.; Zhang, X.; Dai, B.; Cao, M.; Shao, R.; Zhang, R.; et al. Auranofin-mediated inhibition of $\mathrm{PI} 3 \mathrm{~K} / \mathrm{AKT} / \mathrm{mTOR}$ axis and anticancer activity in non-small cell lung cancer cells. Oncotarget 2016, 7, 3548. [CrossRef] [PubMed]

178. Mirabelli, C.K.; Johnson, R.K.; Hill, D.T.; Faucette, L.F.; Girard, G.R.; Kuo, G.Y.; Sung, C.M.; Crooke, S.T. Correlation of the in vitro cytotoxic and in vivo antitumor activities of gold(I) coordination complexes. J. Med. Chem. 1986, 29, 218-223. [CrossRef]

179. Regala, R.P.; Thompson, E.A.; Fields, A.P. Atypical protein kinase Cı expression and aurothiomalate sensitivity in human lung cancer cells. Cancer Res. 2008, 68, 5888-5895. [CrossRef] [PubMed]

180. Mansfield, A.S.; Fields, A.P.; Jatoi, A.; Qi, Y.; Adjei, A.A.; Erlichman, C.; Molina, J.R. Phase I dose escalation study of the PKCı inhibitor aurothiomalate for advanced non-small-cell lung cancer, ovarian cancer, and pancreatic cancer. Anticancer Drugs 2013, 24, 1079-1083. [CrossRef] [PubMed]

181. Jatoi, A.; Radecki Breitkopf, C.; Foster, N.R.; Block, M.S.; Grudem, M.; Wahner Hendrickson, A.; Carlson, R.E.; Barrette, B.; Karlin, N.; Fields, A.P. A mixed-methods feasibility trial of protein kinase $\mathrm{C} \iota$ inhibition with auranofin in asymptomatic ovarian cancer patients. Oncology 2015, 88, 208-213. [CrossRef] [PubMed] 
182. Kambhampati, S. Phase I and II Study of Auranofin in Chronic Lymphocytic Leukemia. 2016. Available online: https:// clinicaltrials.gov/ct2/show / NCT01419691?term=auranofin\&draw=2\&rank=4 (accessed on 24 September 2020).

183. Pillai, P.; Desai, S.; Patel, R.; Sajan, M.; Farese, R.; Ostrov, D.; Acevedo-Duncan, M. A novel PKC-ı inhibitor abrogates cell proliferation and induces apoptosis in neuroblastoma. Int. J. Biochem. Cell Biol. 2011, 43, 784-794. [CrossRef] [PubMed]

184. Ratnayake, W.S.; Apostolatos, C.A.; Apostolatos, A.H.; Schutte, R.J.; Huynh, M.A.; Ostrov, D.A.; Acevedo-Duncan, M. Oncogenic PKC- $\iota$ activates Vimentin during epithelial-mesenchymal transition in melanoma; a study based on PKC- $\iota$ and PKC- $\zeta$ specific inhibitors. Cell Adhes. Migr. 2018, 12, 47-463. [CrossRef]

185. Apostolatos, A.H.; Ratnayake, W.S.; Win-Piazza, H.; Apostolatos, C.A.; Smalley, T.; Kang, L.; Salup, R.; Hill, R.; Acevedo-Duncan, $\mathrm{M}$. Inhibition of atypical protein kinase $\mathrm{C}-\iota$ effectively reduces the malignancy of prostate cancer cells by downregulating the NF-kB signaling cascade. Int. J. Oncol. 2018, 53, 1836-1846. [CrossRef]

186. Acevedo-Duncan, M.E. In vivo effects of ICA-1 on breast cancer and glioma xenografts. Cancer Res. 2021, 72 (Suppl. 8), 2827.

187. Islam, S.M.A.; Patel, R.; Acevedo-Duncan, M. Protein Kinase C- $\zeta$ stimulates colorectal cancer cell carcinogenesis via PKC$\zeta / \operatorname{Rac} 1 /$ Pak1/ $\beta$-Catenin signaling cascade. Biochim. Biophys. Acta Mol. Cell. Res. 2018, 1865, 650-664. [CrossRef] [PubMed]

188. Smalley, T.; Metcalf, R.; Patel, R.; Islam, S.M.S.; Bommareddy, R.R.; Acevedo-Duncan, M. The atypical protein kinase C small molecule inhibitor $\zeta$-Stat, and its effects on invasion through decreases in PKC- $\zeta$ protein expression. Front. Oncol. 2020, 10, 209. [CrossRef] [PubMed]

189. Ratnayake, W.S.; Apostolatos, A.H.; Ostrov, D.A.; Acevedo-Duncan, M. Two novel atypical PKC inhibitors; ACPD and DNDA effectively mitigate cell proliferation and epithelial to mesenchymal transition of metastatic melanoma while inducing apoptosis. Int. J. Oncol. 2017, 51, 1370-1382. [CrossRef]

190. Chen, T.C.; Lee, R.A.; Tsai, S.L.; Kanamaluru, D.; Gray, N.E.; Yiv, N.; Cheang, R.T.; Tan, J.H.; Lee, J.Y.; Fitch, M.D.; et al. An ANGPTL4-ceramide-protein kinase $\mathrm{C} \zeta$ axis mediates chronic glucocorticoid exposure-induced hepatic steatosis and hypertriglyceridemia in mice. J. Biol. Chem. 2019, 294, 9213-9224. [CrossRef]

191. Sajan, M.P.; Ivey, R.A.; Lee, M.C.; Farese, R.V. Hepatic insulin resistance in ob/ob mice involves increases in ceramide, aPKC activity, and selective impairment of Akt-dependent FoxO1 phosphorylation. J. Lipid Res. 2015, 56, 70-80. [CrossRef] [PubMed]

192. Kang, J.H.; Inokuchi, J.; Kawano, T.; Murata, M. Protein kinase C $\alpha$ as a therapeutic target in cancer. In Protein Kinase C: Emerging Roles and Therapeutic Potential; Pierce, D.N., Ed.; Nova Science Publishers, Inc.: New York, NY, USA, 2018; pp. $25-47$.

193. Grossman, S.A.; Alavi, J.B.; Supko, J.G.; Carson, K.A.; Priet, R.; Dorr, F.A.; Grundy, J.S.; Holmlund, J.T. Efficacy and toxicity of the antisense oligonucleotide aprinocarsen directed against protein kinase $\mathrm{C}-\alpha$ delivered as a 21-day continuous intravenous infusion in patients with recurrent high-grade astrocytomas. Neuro-Oncology 2005, 7, 32-40. [CrossRef]

194. Paz-Ares, L.; Douillard, J.Y.; Koralewski, P.; Manegold, C.; Smit, E.F.; Reyes, J.M.; Chang, G.C.; John, W.J.; Peterson, P.M.; Obasaju, C.K.; et al. Phase III study of gemcitabine and cisplatin with or without aprinocarsen, a protein kinase C-alpha antisense oligonucleotide, in patients with advanced-stage non-small-cell lung cancer. J. Clin. Oncol. 2006, 24, 1428-1434. [CrossRef] [PubMed]

195. Ritch, P.; Rudin, C.M.; Bitran, J.D.; Edelman, M.J.; Makalinao, A.; Irwin, D.; Lilenbaum, R.; Peterson, P.; John, W.J. Phase II study of PKC- $\alpha$ antisense oligonucleotide aprinocarsen in combination with gemcitabine and carboplatin in patients with advanced non-small cell lung cancer. Lung Cancer 2006, 52, 173-180. [CrossRef] [PubMed]

196. Advani, R.; Peethambaram, P.; Lum, B.L.; Fisher, G.A.; Hartmann, L.; Long, H.J.; Halsey, J.; Holmlund, J.T.; Dorr, A.; Sikic, B.I. A Phase II trial of aprinocarsen, an antisense oligonucleotide inhibitor of protein kinase $C \alpha$, administered as a 21-day infusion to patients with advanced ovarian carcinoma. Cancer 2004, 100, 321-326. [CrossRef]

197. Tolcher, A.W.; Reyno, L.; Venner, P.M.; Ernst, S.D.; Moore, M.; Geary, R.S.; Chi, K.; Hall, S.; Walsh, W.; Dorr, A.; et al. A randomized phase II and pharmacokinetic study of the antisense oligonucleotides ISIS 3521 and ISIS 5132 in patients with hormone-refractory prostate cancer. Clin. Cancer Res. 2002, 8, 2530-2535.

198. Marshall, J.L.; Eisenberg, S.G.; Johnson, M.D.; Hanfelt, J.; Dorr, F.A.; El-Ashry, D.; Oberst, M.; Fuxman, Y.; Holmlund, J.; Malik, S. A phase II trial of ISIS 3521 in patients with metastatic colorectal cancer. Clin. Colorectal Cancer 2004, 4, 268-274. [CrossRef] [PubMed]

199. Rao, S.; Watkins, D.; Cunningham, D.; Dunlop, D.; Johnson, P.; Selby, P.; Hancock, B.W.; Fegan, C.; Culligan, D.; Schey, S.; et al. Phase II study of ISIS 3521, an antisense oligodeoxynucleotide to protein kinase C alpha, in patients with previously treated low-grade non-Hodgkin's lymphoma. Ann. Oncol. 2004, 15, 1413-1418. [CrossRef] [PubMed]

200. Strair, R.K.; Schaar, D.; Goodell, L.; Aisner, J.; Chin, K.V.; Eid, J.; Senzon, R.; Cui, X.X.; Han, Z.T.; Knox, B.; et al. Administration of a phorbol ester to patients with hematological malignancies: Preliminary results from a phase I clinical trial of 12-O-tetradecanoylphorbol-13-acetate. Clin. Cancer Res. 2002, 8, 2512-2518.

201. Schaar, D.; Goodell, L.; Aisner, J.; Cui, X.X.; Han, Z.T.; Chang, R.; Martin, J.; Grospe, S.; Dudek, L.; Riley, J.; et al. A phase I clinical trial of 12-O-tetradecanoylphorbol-13-acetate for patients with relapsed/refractory malignancies. Cancer Chemother. Pharmacol. 2006, 57, 789-795. [CrossRef] [PubMed]

202. Kortmansky, J.; Schwartz, G.K. Bryostatin-1: A novel PKC inhibitor in clinical development. Cancer Investig. 2003, 21, 924-936. [CrossRef]

203. Propper, D.J.; Macaulay, V.; O’Byrne, K.J.; Braybrooke, J.P.; Wilner, S.M.; Ganesan, T.S.; Talbot, D.C.; Harris, A.L. A phase II study of bryostatin 1 in metastatic malignant melanoma. Br. J. Cancer 1998, 78, 1337-1341. [CrossRef] 
204. Bedikian, A.Y.; Plager, C.; Stewart, J.R.; O’Brian, C.A.; Herdman, S.K.; Ross, M.; Papadopoulos, N.; Eton, O.; Ellerhorst, J.; Smith, T. Phase II evaluation of bryostatin-1 in metastatic melanoma Phase II evaluation of bryostatin-1 in metastatic melanoma. Melanoma Res. 2001, 11, 183-188. [CrossRef] [PubMed]

205. Tozer, R.G.; Burdette-Radoux, S.; Berlanger, K.; Davis, M.L.; Lohmann, R.C.; Rusthoven, J.R.; Wainman, N.; Zee, B.; Seymour, L.; National Cancer Institute of Canada Clinical Trials Group. A randomized phase II study of two schedules of bryostatin-1 (NSC339555) in patients with advanced malignant melanoma: A National Cancer Institute of Canada Clinical Trials Group Study. Investig. New Drugs 2002, 20, 407-412. [CrossRef] [PubMed]

206. Pagliaro, L.; Daliani, D.; Amato, R.; Tu, S.M.; Jones, D.; Smith, T.; Logothetis, C.; Millikan, R. A phase II trial of bryostatin-1 for patients with metastatic renal cell carcinoma. Cancer 2000, 89, 615-618. [CrossRef]

207. Madhusudan, S.; Protheroe, A.; Propper, D.; Han, C.; Corrie, P.; Earl, H.; Hancock, B.; Vasey, P.; Turner, A.; Balkwill, F.; et al. A multicentre phase II trial of bryostatin-1 in patients with advanced renal cancer. Br. J. Cancer 2003, 89, 1418-1422. [CrossRef] [PubMed]

208. Zonder, J.A.; Shields, A.F.; Zalupski, M.; Chaplen, R.; Heilbrun, L.K.; Arlauskas, P.; Philip, P.A. A phase II trial of bryostatin 1 in the treatment of metastatic colorectal cancer. Clin. Cancer Res. 2001, 7, 38-42. [PubMed]

209. Blackhall, F.H.; Ranson, M.; Radford, J.A.; Hancock, B.W.; Soukop, M.; McGown, A.T.; Robbins, A.; Halbert, G.; Jayson, G.C.; Cancer Research Campaign Phase I/II Committee. A phase II trial of bryostatin 1 in patients with non-Hodgkin's lymphoma. Br. J. Cancer 2001, 84, 465-469. [CrossRef] [PubMed]

210. Varterasian, M.L.; Pemberton, P.A.; Hulburd, K.; Rodriguez, D.H.; Murgo, A.; Al-Katib, A.M. Phase II study of bryostatin 1 in patients with relapsed multiple myeloma. Investig. New Drugs 2001, 19, 245-247. [CrossRef]

211. Brockstein, B.; Samuels, B.; Humerickhouse, R.; Arietta, R.; Fishkin, P.; Wade, J.; Sosman, J.; Vokes, E.E. Phase II studies of bryostatin-1 in patients with advanced sarcoma and advanced head and neck cancer. Investig. New Drugs 2001, 19, 249-254. [CrossRef] [PubMed]

212. Pfister, D.G.; McCaffrey, J.; Zahalsky, A.J.; Schwartz, G.K.; Lis, E.; Gerald, W.; Huvos, A.; Shah, J.; Kraus, D.; Shaha, A.; et al. A phase II trial of bryostatin-1 in patients with metastatic or recurrent squamous cell carcinoma of the head and neck. Investig. New Drugs 2002, 20, 123-127. [CrossRef]

213. Armstrong, D.K.; Blessing, J.A.; Rader, J.; Sorosky, J.L.; Gynecologic Oncology Group Study. A randomized phase II evaluation of bryostatin-1 (NSC \#339555) in persistent or recurrent squamous cell carcinoma of the cervix: A Gynecologic Oncology Group Study. Investig. New Drugs 2003, 21, 453-457. [CrossRef]

214. Clamp, A.R.; Blackhall, F.H.; Vasey, P.; Soukop, M.; Coleman, R.; Halbert, G.; Robson, L.; Jayson, G.C.; Cancer Research UK Phase I/II Committee. A phase II trial of bryostatin-1 administered by weekly 24-hour infusion in recurrent epithelial ovarian carcinoma. Br. J. Cancer 2003, 89, 1152-1154. [CrossRef] [PubMed]

215. Lam, A.P.; Sparano, J.A.; Vinciguerra, V.; Ocean, A.J.; Christos, P.; Hochster, H.; Camacho, F.; Goel, S.; Mani, S.; Kaubisch, A. Phase II study of paclitaxel plus the protein kinase $\mathrm{C}$ inhibitor bryostatin-1 in advanced pancreatic carcinoma. Am. J. Clin. Oncol. 2010, 33, 121-124. [CrossRef] [PubMed]

216. Winegarden, J.D.; Mauer, A.M.; Gajewski, T.F.; Hoffman, P.C.; Krauss, S.; Rudin, C.M.; Vokes, E.E. A phase II study of bryostatin-1 and paclitaxel in patients with advanced non-small cell lung cancer. Lung Cancer 2003, 39, 191-196. [CrossRef]

217. Nezhat, F.; Wadler, S.; Muggia, F.; Mandeli, J.; Goldberg, G.; Rahaman, J.; Runowicz, C.; Murgo, A.J.; Gardner, G.J. Phase II trial of the combination of bryostatin-1 and cisplatin in advanced or recurrent carcinoma of the cervix: A New York Gynecologic Oncology Group study. Gynecol. Oncol. 2004, 93, 144-148. [CrossRef]

218. Peterson, A.C.; Harlin, H.; Karrison, T.; Vogelzang, N.J.; Knost, J.A.; Kugler, J.W.; Lester, E.; Vokes, E.; Gajewski, T.F.; Stadler, W.M.; et al. A randomized phase II trial of interleukin-2 in combination with four different doses of bryostatin-1 in patients with renal cell carcinoma. Investig. New Drugs 2006, 24, 141-149. [CrossRef]

219. Ajani, J.A.; Jiang, Y.; Faust, J.; Chang, B.B.; Ho, L.; Yao, J.C.; Rousey, S.; Dakhil, S.; Cherny, R.C.; Craig, C.; et al. A multicenter phase II study of sequential paclitaxel and bryostatin-1 (NSC 339555) in patients with untreated, advanced gastric or gastroesophageal junction adenocarcinoma. Investig. New Drugs 2006, 24, 353-357. [CrossRef]

220. Ku, G.Y.; Ilson, D.H.; Schwartz, L.H.; Capanu, M.; O’Reilly, E.; Shah, M.A.; Kelsen, D.P.; Schwartz, G.K. Phase II trial of sequential paclitaxel and $1 \mathrm{~h}$ infusion of bryostatin-1 in patients with advanced esophageal cancer. Cancer Chemother. Pharmacol. 2008, 62, 875-880. [CrossRef] [PubMed]

221. Morgan, R.J.; Leong, L.; Chow, W.; Gandara, D.; Frankel, P.; Garcia, A.; Lenz, H.J.; Doroshow, J.H. Phase II trial of bryostatin-1 in combination with cisplatin in patients with recurrent or persistent epithelial ovarian cancer: A California cancer consortium study. Investig. New Drugs 2012, 30, 723-728. [CrossRef] [PubMed]

222. Barr, P.M.; Lazarus, H.M.; Cooper, B.W.; Schluchter, M.D.; Panneerselvam, A.; Jacobberger, J.W.; Hsu, J.W.; Janakiraman, N.; Simic, A.; Dowlati, A.; et al. Phase II study of bryostatin 1 and vincristine for aggressive non-Hodgkin lymphoma relapsing after an autologous stem cell transplant. Am. J. Hematol. 2009, 84, 484-487. [CrossRef]

223. Hongpaisan, J.; Sun, M.K.; Alkon, D.L. PKC $\varepsilon$ activation prevents synaptic loss, A $\beta$ elevation, and cognitive deficits in Alzheimer's disease transgenic mice. J. Neurosci. 2011, 31, 630-643. [CrossRef]

224. Sen, A.; Nelson, T.J.; Alkon, D.L.; Hongpaisan, J. Loss in PKC€ causes downregulation of MnSOD and BDNF expression in neurons of Alzheimer's disease hippocampus. J. Alzheimers Dis. 2018, 63, 1173-1189. [CrossRef] 
225. Zhu, G.; Wang, D.; Lin, Y.H.; McMahon, T.; Koo, E.H.; Messing, R.O. Protein kinase C $\epsilon$ suppresses A $\beta$ production and promotes activation of $\alpha$-secretase. Biochem. Biophys. Res. Commun. 2001, 285, 997-1006. [CrossRef] [PubMed]

226. Nelson, T.J.; Sun, M.K.; Lim, C.; Sen, A.; Khan, T.; Chirila, F.V.; Alkon, D.L. Bryostatin effects on cognitive function and PKC $\epsilon$ in Alzheimer's disease phase IIa and expanded access trials. J. Alzheimers Dis. 2017, 58, 521-535. [CrossRef] [PubMed]

227. Farlow, M.R.; Thompson, R.E.; Wei, L.J.; Tuchman, A.J.; Grenier, E.; Crockford, D.; Wilke, S.; Benison, J.; Alkon, D.L. A randomized, double-blind, placebo-controlled, phase II study assessing safety, tolerability, and efficacy of bryostatin in the treatment of moderately severe to severe Alzheimer's disease. J. Alzheimers Dis. 2019, 67, 555-570. [CrossRef] [PubMed]

228. Mehla, R.; Bivalkar-Mehla, S.; Zhang, R.; Handy, I.; Albrecht, H.; Giri, S.; Nagarkatti, P.; Nagarkatti, M.; Chauhan, A. Bryostatin modulates latent HIV-1 infection via PKC and AMPK signaling but inhibits acute infection in a receptor independent manner. PLoS ONE 2010, 5, e11160. [CrossRef] [PubMed]

229. Pérez, M.; de Vinuesa, A.G.; Sanchez-Duffhues, G.; Marquez, N.; Bellido, M.L.; Muñoz-Fernandez, M.A.; Moreno, S.; Castor, T.P.; Calzado, M.A.; Muñoz, E. Bryostatin-1 synergizes with histone deacetylase inhibitors to reactivate HIV-1 from latency. Curr. HIV Res. 2010, 8, 418-429. [CrossRef] [PubMed]

230. Gutiérrez, C.; Serrano-Villar, S.; Madrid-Elena, N.; Pérez-Elías, M.J.; Martín, M.E.; Barbas, C.; Ruipérez, J.; Muñoz, E.; MuñozFernández, M.A.; Castor, T.; et al. Bryostatin-1 for latent virus reactivation in HIV-infected patients on antiretroviral therapy. AIDS 2016, 30, 1385-1392. [CrossRef] [PubMed]

231. Khan, T.K.; Sen, A.; Hongpaisan, J.; Lim, C.S.; Nelson, T.J.; Alkon, D.L. PKC $\varepsilon$ deficits in Alzheimer's disease brains and skin fibroblasts. J. Alzheimers Dis. 2015, 43, 491-509. [CrossRef] [PubMed]

232. Talman, V.; Pascale, A.; Jäntti, M.; Amadio, M.; Tuominen, R.K. Protein kinase C activation as a potential therapeutic strategy in Alzheimer's disease: Is there a role for embryonic lethal abnormal vision-like proteins? Basic Clin. Pharmacol. Toxicol. 2016, 119, 149-160. [CrossRef] [PubMed]

233. Sun, M.; Zhang, H. Par3 and aPKC regulate BACE1 endosome-to-TGN trafficking through PACS1. Neurobiol. Aging 2017, 60, 129-140. [CrossRef]

234. Sajan, M.P.; Hansen, B.C.; Higgs, M.G.; Kahn, C.R.; Braun, U.; Leitges, M.; Park, C.R.; Diamond, D.M.; Farese, R.V. Atypical PKC, $\operatorname{PKC} \lambda / \mathrm{l}$, activates $\beta$-secretase and increases $A \beta_{1-40 / 42}$ and phospho-tau in mouse brain and isolated neuronal cells, and may link hyperinsulinemia and other aPKC activators to development of pathological and memory abnormalities in Alzheimer's disease. Neurobiol. Aging 2018, 61, 225-237. [CrossRef]

235. Du, Y.; Zhao, Y.; Li, C.; Zheng, Q.; Tian, J.; Li, Z.; Huang, T.Y.; Zhang, W.; Xu, H. Inhibition of PKC $\delta$ reduces amyloid- $\beta$ levels and reverses Alzheimer disease phenotypes. J. Exp. Med. 2018, 215, 1665-1677. [CrossRef]

236. Boucau, J.; Das, J.; Joshi, N.; Le Gall, S. Latency reversal agents modulate HIV antigen processing and presentation to CD8 T cells. PLoS Pathog. 2020, 16, e1008442. [CrossRef] [PubMed]

237. Sloane, J.L.; Benner, N.L.; Keenan, K.N.; Zang, X.; Soliman, M.S.A.; Wu, X.; Dimapasoc, M.; Chun, T.W.; Marsden, M.D.; Zack, J.A.; et al. Prodrugs of PKC modulators show enhanced HIV latency reversal and an expanded therapeutic window. Proc. Natl. Acad. Sci. USA 2020, 117, 10688-10698. [CrossRef]

238. Zaikos, T.D.; Painter, M.M.; Sebastian Kettinger, N.T.; Terry, V.H.; Collins, K.L. Class 1-Selective Histone Deacetylase (HDAC) Inhibitors enhance HIV latency reversal while preserving the activity of HDAC isoforms necessary for maximal HIV gene expression. J. Virol. 2018, 92, e02110-17. [CrossRef] [PubMed]

239. De la Torre-Tarazona, H.E.; Jiménez, R.; Bueno, P.; Camarero, S.; Román, L.; Fernández-García, J.L.; Beltrán, M.; Nothias, L.F.; Cachet, X.; Paolini, J.; et al. 4-Deoxyphorbol inhibits HIV-1 infection in synergism with antiretroviral drugs and reactivates viral reservoirs through PKC/MEK activation synergizing with vorinostat. Biochem. Pharmacol. 2020, 177, 113937. [CrossRef]

240. Palaniyandi, S.S.; Sun, L.; Ferreira, J.C.; Mochly-Rosen, D. Protein kinase C in heart failure: A therapeutic target? Cardiovasc. Res. 2009, 82, 229-239. [CrossRef] [PubMed]

241. Singh, R.M.; Cummings, E.; Pantos, C.; Singh, J. Protein kinase C and cardiac dysfunction: A review. Heart Fail. Rev. 2017, 22, 843-859. [CrossRef]

242. Bates, E.; Bode, C.; Costa, M.; Gibson, C.M.; Granger, C.; Green, C.; Grimes, K.; Harrington, R.; Huber, K.; Kleiman, N.; et al. Intracoronary KAI-9803 as an adjunct to primary percutaneous coronary intervention for acute ST-segment elevation myocardial infarction. Circulation 2008, 117, 886-896. [CrossRef]

243. Garg, R.; Benedetti, L.G.; Abera, M.B.; Wang, H.; Abba, M.; Kazanietz, M.G. Protein kinase C and cancer: What we know and what we do not. Oncogene 2014, 33, 5225-5237. [CrossRef]

244. Cooke, M.; Magimaidas, A.; Casado-Medrano, V.; Kazanietz, M.G. Protein kinase C in cancer: The top five unanswered questions. Mol. Carcinog. 2017, 56, 1531-1542. [CrossRef] [PubMed]

245. André, F.; Ciruelos, E.; Rubovszky, G.; Campone, M.; Loibl, S.; Rugo, H.S.; Iwata, H.; Conte, P.; Mayer, I.A.; Kaufman, B.; et al. Alpelisib for PIK3CA-mutated, hormone receptor-positive advanced breast cancer. N. Engl. J. Med. 2019, 380, 1929-1940. [CrossRef] [PubMed]

246. Sapon-Cousineau, V.; Sapon-Cousineau, S.; Assouline, S. PI3K inhibitors and their role as novel agents for targeted therapy in lymphoma. Curr. Treat Options Oncol. 2020, 21, 51. [CrossRef] [PubMed]

247. Rodrigues, D.A.; Sagrillo, F.S.; Fraga, C.A.M. Duvelisib: A 2018 novel FDA-approved small molecule inhibiting phosphoinositide 3-kinases. Pharmaceuticals 2019, 12, 69. [CrossRef] [PubMed] 